\title{
Incorporation of crop phenology in Simple Biosphere Model (SiBcrop) to improve land-atmosphere carbon exchanges from croplands
}

\author{
E. Lokupitiya ${ }^{1}$, S. Denning ${ }^{1}$, K. Paustian ${ }^{2,3}$, I. Baker ${ }^{1}$, K. Schaefer ${ }^{4}$, S. Verma $^{5}$, T. Meyers ${ }^{6}$, C. J. Bernacchi ${ }^{7}$, \\ A. Suyker ${ }^{5}$, and M. Fischer ${ }^{8}$ \\ ${ }^{1}$ Department of Atmospheric Science, Colorado State University, Fort Collins, CO 80523, USA \\ ${ }^{2}$ Department of Soil and Crop Sciences, Colorado State University, Fort Collins, CO 80523, USA \\ ${ }^{3}$ Natural Resource Ecology Laboratory, Colorado State University, Fort Collins, CO 80523, USA \\ ${ }^{4}$ National Snow and Ice Data Center, University of Colorado, Boulder, CO 80309, USA \\ ${ }^{5}$ School of Natural Resources, University of Nebraska-Lincoln, Lincoln, NE 68583-0978, USA \\ ${ }^{6}$ NOAA/ARL/ATDD, Oak Ridge, TN 37830-2456, USA \\ ${ }^{7}$ Department of Plant Biology, University of Illinois at Urbana-Champaign, Champaign, IL 61820, USA \\ ${ }^{8}$ Lawrence Berkeley National Laboratory, Environmental Energy Technologies Division, \\ Atmospheric Science Department, Berkeley, CA 94720, USA
}

Received: 8 December 2008 - Published in Biogeosciences Discuss.: 10 February 2009

Revised: 8 May 2009 - Accepted: 25 May 2009 - Published: 12 June 2009

\begin{abstract}
Croplands are man-made ecosystems that have high net primary productivity during the growing season of crops, thus impacting carbon and other exchanges with the atmosphere. These exchanges play a major role in nutrient cycling and climate change related issues. An accurate representation of crop phenology and physiology is important in land-atmosphere carbon models being used to predict these exchanges. To better estimate time-varying exchanges of carbon, water, and energy of croplands using the Simple Biosphere ( $\mathrm{SiB}$ ) model, we developed crop-specific phenology models and coupled them to $\mathrm{SiB}$. The coupled SiBphenology model (SiBcrop) replaces remotely-sensed NDVI information, on which $\mathrm{SiB}$ originally relied for deriving Leaf Area Index (LAI) and the fraction of Photosynthetically Active Radiation (fPAR) for estimating carbon dynamics. The use of the new phenology scheme within $\mathrm{SiB}$ substantially improved the prediction of LAI and carbon fluxes for maize, soybean, and wheat crops, as compared with the observed data at several AmeriFlux eddy covariance flux tower sites in the US mid continent region. SiBcrop better predicted the onset and end of the growing season, harvest, interannual variability associated with crop rotation, day time car-
\end{abstract}

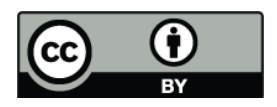

Correspondence to: E. Lokupitiya (erandi@atmos.colostate.edu) bon uptake (especially for maize) and day to day variability in carbon exchange. Biomass predicted by SiBcrop had good agreement with the observed biomass at field sites. In the future, we will predict fine resolution regional scale carbon and other exchanges by coupling SiBcrop with RAMS (the Regional Atmospheric Modeling System).

\section{Introduction}

Trends in global warming and climate change have drawn more attention towards anthropogenic emissions of greenhouse gases. Carbon dioxide $\left(\mathrm{CO}_{2}\right)$ has been identified as the main anthropogenic greenhouse gas contributing to climate change (IPCC, 2007). Land-atmosphere exchanges of energy, water vapor and $\mathrm{CO}_{2}$ play a major role in climate change and its long-term consequences. A powerful way to evaluate these exchanges is to model the fluxes between the land and atmosphere using reliable land surface models, while evaluating the outcome against observed data. The performance of those models depends on how well they can simulate the vegetation properties and dynamics over time and space. This study focuses on estimating the $\mathrm{CO}_{2}$ exchanges in cropland ecosystems, evaluated against AmeriFlux eddy covariance flux tower sites with maize, soybean, and wheat crops (Fig. 1). During the growing season, the presence of

Published by Copernicus Publications on behalf of the European Geosciences Union. 

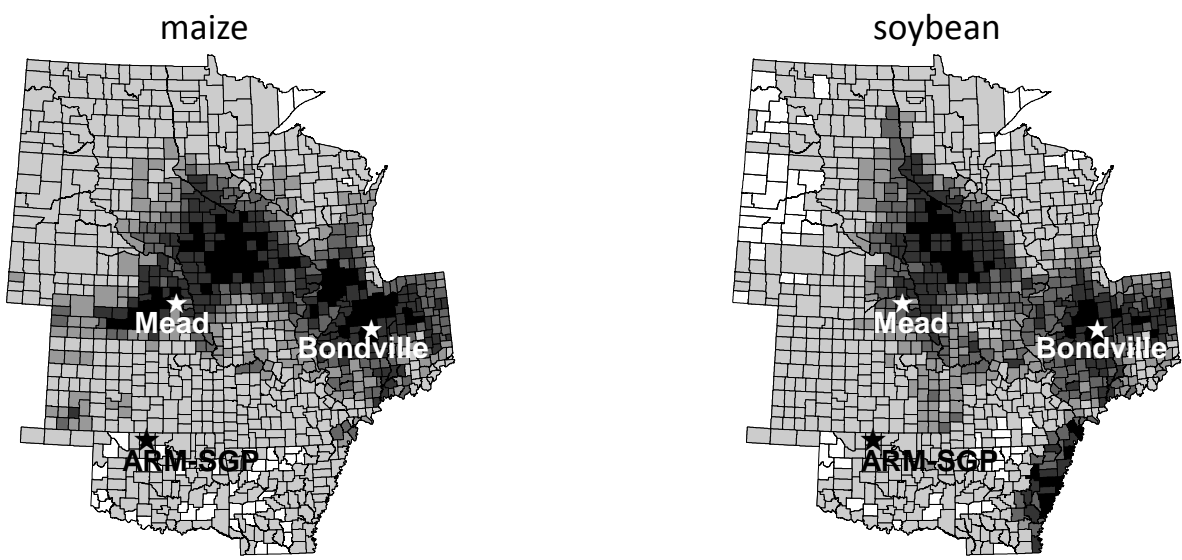

wheat

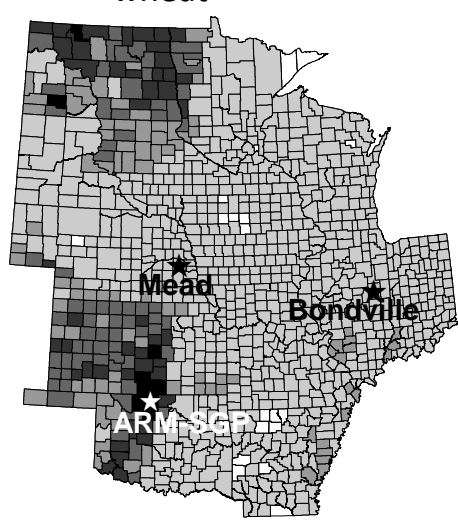

percent crop area

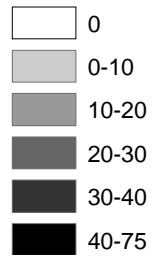

Fig. 1. Distribution of maize, soybean, and wheat in the US mid west region encompassing the eddy covariance flux tower sites used for model testing (i.e. Bondville, IL, Mead, NE, and ARM-SGP, OK; marked with asterisk). Crop areas are presented as a percentage of the county area (Source: NASSus database; Lokupitiya et al., 2007).

crops significantly impacts $\mathrm{CO}_{2}$ fluxes, as well as albedo, roughness length, Bowen ratio, and soil moisture. Therefore, an accurate representation of crop phenology (i.e., timing of different growth stages) and physiology is important in predicting carbon and other exchanges of these managed ecosystems (Betts, 2005; Hansen et al., 2006; Desjardins et al., 2007).

Croplands include a variety of species with different phenology and physiology. Crops have either C3 or C4 photosynthetic pathways and the associated differences in plant anatomy and physiology. Croplands have unique dynamics as managed ecosystems that are mostly governed by the dates of planting and harvest, crop rotation, tillage, fertilization, irrigation, and pest control. Most croplands are characterized by high rates of $\mathrm{CO}_{2}$ uptake and net primary productivity (NPP) over their short growing seasons. Although certain croplands may physically resemble grasslands (i.e. compared to forests), they differ substantially in terms of seasonality, phenology and physiology, and harvested products, which can account for $40-60 \%$ of the above ground biomass (Hay, 1995; Prince et al., 2001; Rao et al., 2002; Heard, 2004) that is exported after the crop reaches maturity. Therefore mod- els that simulate agricultural ecosystems should have a good representation of the crop phenology and physiology that are associated with the unique properties of these ecosystems.

Most of the existing models for simulating phenology, physiology, growth, carbon, nutrient and water fluxes of specific crops, are complex, process-based models and have used different strategies in simulating cropland dynamics. For instance, Gervois et al. (2004) and de Noblet-Ducoudré et al. (2005) combined an existing agronomy model (STICS), which has a daily time step and the ability to simulate several crops (maize, wheat, and soybean) to the soil-vegetation atmosphere scheme of an existing dynamic global vegetation model (ORCHIDEE) with a 30-min time step, to improve the carbon and water exchanges from croplands predicted by the latter model. The coupled model performs at a 30-min timestep (Gervois et al., 2004). Similarly, the suite of CROPGRO and CERES models (e.g., Jones and Kiniry, 1986, Kiniry, 1991, Ritchie, 1991, Boote et al., 1998) were developed to simulate crop-specific detailed physiology and phenology of several cereals, legume and other crops. These models have daily time step, detailed physiology, represented by algorithms for estimating photosynthesis, dry 
matter partitioning, water, and energy fluxes from crop vegetation, and uses Weather, soil, management data as the inputs. Bondeau et al. (2007) have simulated global and grid scale carbon fluxes and yields for different annual crop functional types (CFTs; altogether 13-11 arable crops and 2 managed grass types) using a global scale dynamic vegetation model for managed land, Lund-Postsdam-Jena managed land (LPJmL), with monthly weather data and a weather generator to obtain the daily distribution of the weather. In addition to predicting the fluxes for CFTs, the model also predicts carbon fluxes for the natural plant functional types (PFTs; Bondeau et al., 2007). Recent work at the National Center for Atmospheric Research (NCAR) includes the addition of crop-related information (i.e. planting, allocation, phenology, etc.) from Agro-IBIS model (i.e. a process-based, terrestrial ecosystem model; Kucharik and Byre, 2003) to improve the cropland representation by the land surface parameterization in the Community Land Model (CLM (Oleson et al., 2008); S. Levis, personal communication, 2008). The new coupled model, which includes crop life cycles and carbon and nitrogen algorithms from Agro-IBIS, is referred to as $\mathrm{CN}$-crop. $\mathrm{CN}$-crop has the ability to simulate maize, wheat, and soybean (in contrast to the original CLM, which considers a generic crop that is modeled like a grass) at half hourly intervals. The above models have complex physiology and built in phenology mostly governed by temperature (i.e. thermal time or growing degree days).

Since croplands seem to play a role in large-scale climate feedbacks, coupling crop models with climate models has also been done to improve the accuracy of predicting carbon and other exchanges between the atmosphere and biosphere (Betts, 2005). Several of the existing crop models have been already coupled with such climate/land surface models for regional or global scale predictions. For instance, Osborne et al. (2007) coupled the General Large Area Model for annual crops (GLAM; Challinor et al., 2004, 2005), which has a daily time step, within the land surface scheme (i.e. MOSES) of the global climate model (GCM), HadAM3, for simulating groundnut (peanut). MOSES2 provides the lower atmospheric conditions based on the influence from the vegetation, and GLAM simulates crop growth based on the environmental conditions. The coupled model has a half-hourly time step (Osborne et al., 2007). Similarly, CN-crop (described above) has been fully coupled within the Community Climate System Model (CCSM) of NCAR (S. Levis, personal communication, 2008). CERES/DSSAT crop models, which have a daily time step, have also been coupled with climate models in different studies (e.g. Schulze et al., 1993; Takle et al., 2003; Baigorria et al., 2007) for improved prediction of the climate interaction with the cropping systems.

The Simple Biosphere model ( $\mathrm{SiB})$ has been used in estimating land atmosphere exchanges at both global and regional scales (Sellers et al., 1996a, 1996b, Baker et al., 2008). $\mathrm{SiB}$ simulates the biological processes of photosynthesis and respiration and the physical processes of turbulent transport between the land surface and the boundary layer. Biophysical models such as $\mathrm{SiB}$ were originally developed to estimate surface fluxes of latent heat, sensible heat, and momentum in General Circulation Models (Sellers et al., 1986, 1992, 1994, 1997; Los, 1998). The ecosystem fluxes are estimated from leaf-level calculations using scaling assumptions (Sellers et al., 1992) based on nutrient distribution in the canopy.

Originally, planting and harvest events and the presence of alternating crops, etc., were not well represented in SiB. The basis for carbon, moisture, and energy fluxes predicted by $\mathrm{SiB}$ was the leaf area index (LAI) and fraction of photosynthetically active radiation (fPAR) derived from remotely sensed NDVI. The NDVI products minimize cloud contamination by using 15-day or monthly maximum value composites. Interpolation between these composite values leads to mismatches between the actual period of crop presence in the field and that predicted by the NDVI, and the time compositing unrealistically extends the growing season. Any effects from partly-cloudy pixels, aerosols, and smoke, etc., on NDVI, are also reflected in the predicted LAI and fPAR. Compositing also occurs in space as well as time, leading to misrepresentation between the pixel used for the NDVI and the actual conditions in the field. The NDVI and the respiration formulation does not account for crop harvest, forcing an annually balanced carbon budget, when in reality much of the biomass is removed from the site. The result is unrealistic simulated biomass and carbon fluxes, indicating the need for a new crop phenology scheme to reflect highly managed crop ecosystems.

To improve the functionality of $\mathrm{SiB}$ over cropland ecosystems, we developed and evaluated offline crop-specific phenology (and physiology) models for major $\mathrm{C} 3$ and $\mathrm{C} 4$ crops. We coupled these models with $\mathrm{SiB}$, to replace the use of NDVI in predicting LAI and improve the accuracy of the predicted fluxes by $\mathrm{SiB}$. The new model is referred to as SiBcrop. The climate driven dynamic phenology scheme within SiBcrop simulates the daily biomass in different plant pools, LAI, and specific events during crop growth cycle such as planting, emergence, vegetative and reproductive growth stages (Fehr et al., 1971; Ritchie et al., 1992, 1996), harvesting, etc. We evaluated the performance of SiBcrop for maize and soybean, by using observed data at two agricultural eddy covariance flux tower sites in the US Midwest, which have a good record of these crops grown in rotation: Bondville, Illinois (Meyers and Hollinger, 2004), and Mead, Nebraska (Suyker et al., 2004; Verma et al., 2005). We also evaluated the performance of SiBcrop for wheat, using observed data from the Southern Great Plains eddy covariance flux tower site (Fischer et al., 2007) under the Atmospheric Radiation Measurement (ARM) program, in Oklahoma; currently this site, known as ARM-SGP, is the only active wheat site under the AmeriFlux program. 


\section{Materials and methods}

\subsection{Simple biosphere model}

The parameterization of photosynthetic carbon assimilation in $\mathrm{SiB}$ is based on enzyme kinetics originally developed by Farquhar et al. (1980), and is linked to stomatal conductance and thence to the surface energy budget and atmospheric climate (Collatz et al., 1991, 1992; Sellers et al., 1996a; Randall et al., 1996). The model has been updated to include prognostic calculation of temperature, moisture, and trace gases in the canopy air space, and the model has been evaluated against eddy covariance measurements at a number of sites (Baker et al., 2003; Hanan et al., 2004; Vidale and Stöckli, 2005). SiB has been coupled to the Regional Atmospheric Modeling System (RAMS) and used to study PBL-scale interactions among carbon fluxes, turbulence, and $\mathrm{CO}_{2}$ mixing ratio (Denning et al., 2003) and regional-scale controls on $\mathrm{CO}_{2}$ variations (Nicholls et al., 2004; Corbin et al., 2008; Wang et al., 2007). Other recent improvements include biogeochemical fractionation and recycling of stable carbon isotopes (Suits et al., 2005), improved treatment of soil hydrology and thermodynamics, and the introduction of a multilayer snow model based on the Community Land Model (Dai et al., 2003).

The current version (version 3.0) of $\mathrm{SiB}$ (i.e. $\mathrm{SiB} 3$ ) requires the vegetation state, vegetation type, soil characteristics, and weather data as input data. The vegetation state refers to time-dependent properties such as Leaf Area Index (LAI), aerodynamic roughness length, and absorbed fraction of incident visible light (fPAR). The vegetation type determines the physical characteristics of the canopy that do not vary with time, such as the canopy height, leaf transmittance, and photosynthetic capacity (Sellers et al., 1996b). Soil type determines soil hydraulic and thermal properties (Clapp and Hornberger, 1978). Weather data consists of temperature, wind speed, precipitation (convective and stratiform), atmospheric pressure, humidity, and down-welling radiation (shortwave and longwave, direct and diffuse).

Historically, $\mathrm{SiB}$ has used prescribed vegetation parameters derived by remote sensing (Sellers et al., 1996b). At global scale, this approach allows realistic simulation of spatial and temporal variations in vegetation cover and state (Denning et al., 1996a, 1996b; Schaefer et al., 2002, 2005; Baker et al., 2008). At the underlying pixel scale, however, phenology products derived from satellite data must be heavily smoothed to remove dropouts and artifacts introduced by frequent cloud cover. An inevitable trade-off between cloudinduced "noise" in the leaf area and time compositing systematically stretches the seasonal cycle by choosing data late in each compositing period in spring, and early in each composite in fall. Therefore, in this study, we have addressed this problem, by developing and testing a prognostic phenology sub model for $\mathrm{SiB}$, rather than using satellite data for speci- fying crop phenology, while incorporating better parameterization for cropland ecosystems.

We modified the parameters within $\mathrm{SiB}$ to better represent soybean (Glycine max L.; C3), maize (Zea mays L.; C4), and wheat (Triticum aestivum L.; C3), the dominant crops in the US mid western region. Crop specific information and data from past literature were used in modifying the existing parameter values (Table 1). We also modified the algorithm for respiration control, to allow for harvest removal. In $\mathrm{SiB}$, an annual respiring carbon pool is calculated assuming that carbon in the total net photosynthetic assimilation (i.e. gross photosynthesis - canopy maintenance respiration) is added to, and partitioned among the litter and soil layers, and respired within a year, causing an overall annual zero net ecosystem exchange. We modified the annual net photosynthetic assimilation carbon added on the ground (i.e. within different litter and soil layers), to include only the fraction of carbon left after the removal of the harvest (Table 1). We also set the physiological fractions ( $\mathrm{C} 3$ vs $\mathrm{C} 4)$ of the crops in such a way that it could represent any crop rotation, where each subsequent term's crop is planted on the residue of the previous crop.

\subsection{Phenology in SiBcrop}

Phenology events and growth stages were determined by the growing degree days and the number of days since planting. Phenology was calculated once a day within SiBcrop (Fig. 2). The model allocates sub hourly photosynthetic carbon to four different plant pools (leaves, stems, roots and products (flowers, grain, and pods) depending on seasonal development. The daily carbon allocation to leaves was used to update LAI, which was then used to calculate photosynthesis during the following day. We assumed that the crop plants were not limited by nitrogen and other nutrients, as they were well fertilized ( $\mathrm{SiB}$ has indirect representation of nitrogen limitation through Rubisco dynamics within the photosynthetic mechanism). The parameters and functions used in the phenology submodel were specific for different crops, growth stages and plant pools.

\subsubsection{Detailed scheme}

Planting dates for crops were set at the seventh consecutive day on which the air temperature remained above a cropspecific optimal temperature for germination; planting date was readjusted if the temperature dropped below a certain threshold after the initial 7-day period (Pedersen, 2003; Pedersen and Lauer, 2004; USDA, 1997). Plant emergence, subsequent growth stages and phenology events were set based on accumulated growing degree days (Eq. (1)) and the number of days since planting (Taylor et al., 1982; Wells et al., 1986; Ritchie et al., 1996; Heard, 2004).

$G D D=\sum\left(T_{\text {mean }}-T_{\text {base }}\right)$ 
Table 1. Some important crop relevant parameters in SiBcrop; these parameter values are deviations or additions to the parameter values given for $\mathrm{SiB}$ in Sellers et al. (1992, 1996b).

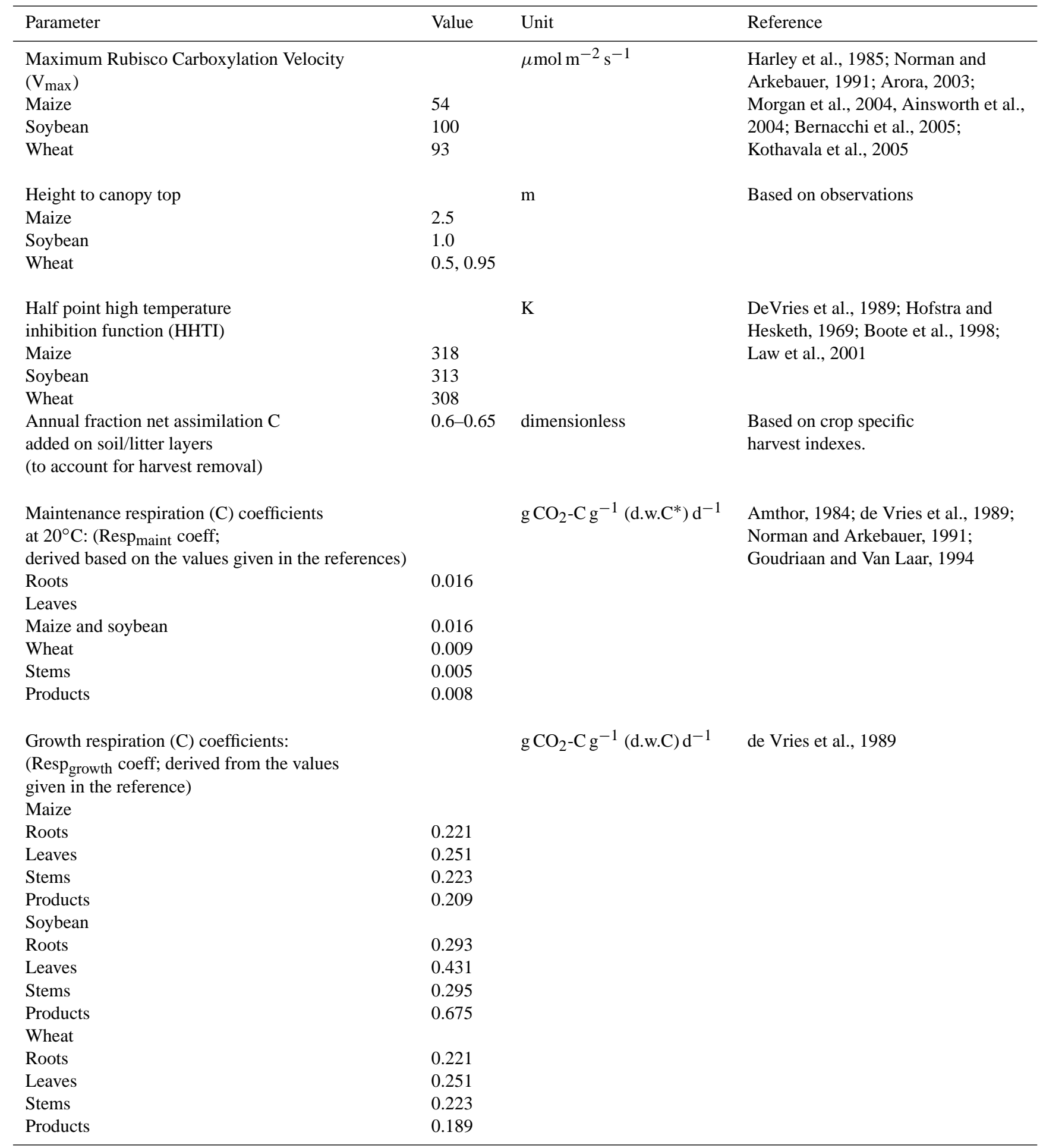

* d.w.C $=$ dry weight (i.e. biomass) carbon 


\section{SiBcrop}

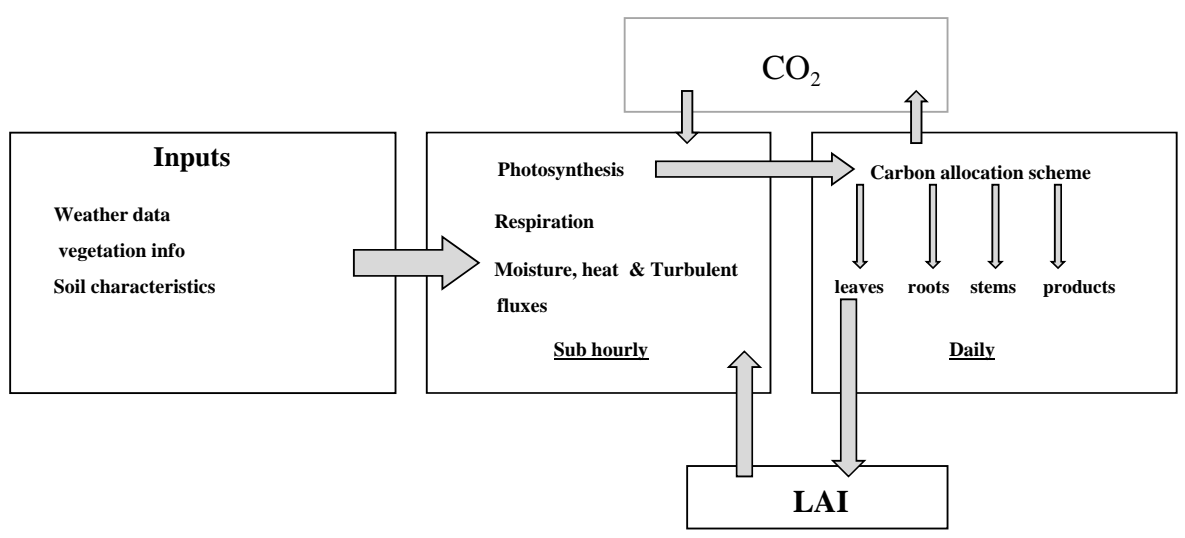

Fig. 2. Methodological Framework.

where $G D D$ is the accumulated daily growing degree days; $T_{\text {mean }}$ is the average daily temperature $\left({ }^{\circ} \mathrm{C}\right) ; T_{\text {base }}$ is the base temperature $\left(10^{\circ} \mathrm{C}\right.$ for maize and soybean, and $0^{\circ} \mathrm{C}$ for winter wheat), above which the growing degree days start to accumulate (there is no accumulation of GDDs below the base temperature or above an optimal temperature, which is $30^{\circ} \mathrm{C}$ for maize and soybean, and $26^{\circ} \mathrm{C}$ for winter wheat; Neild and Newman, 1986; McMaster and Wilhelm, 1998; Cornell University Cooperative Extension, 2008).

In the earliest stages of plant growth, photosynthesis is insufficient to support the development of new biomass. Initial plant growth was assumed to be derived from stored carbon in the seed.

The initial biomass values at emergence (Green and Sudia, 1969; Blum et al., 1980; Smiciklas et al., 1992; Richardson and Bacon, 1993; Pinhero and Fletcher, 1994; Hameed et al., 2003) were set considering the average planting density based on the plant and row spacing typical for each crop. Starting from the day of emergence, a daily LAI value was estimated based on leaf carbon (details follow), for deriving fPAR and estimating sub hourly photosynthetic assimilate, respiratory carbon (i.e. both ground and canopy respiration) and other fluxes during the following day. During the early phase of vegetative development, in which the carbon stored in the seed is utilized for growth (Peterson et al., 1989; McWilliams et al., 1999; Nielsen, 2007), the daily biomass addition/gain rate was set to be optimal, assuming that the seedling is not nutrient limited and that growth is dependent on the temperature and moisture availability (Eq. (2)). The growth rate followed a linear ramp during the initial seedling development.

$M_{d} \approx M_{\text {init }}+\left(t * \frac{\left(M_{\text {max }}-M_{\text {init }}\right)}{\tau_{\text {seed }}}\right) * C_{M} * C_{T}$

where $M_{d}$ is the daily biomass carbon $(\mathrm{C})$ addition/gain rate in the seedling during the initial phase (i.e. the phase in which the seed stored carbon is utilized), assuming optimal nutrient availability $\left(\mathrm{g} \mathrm{C} \mathrm{m}^{-2} \mathrm{~d}^{-1}\right) ; t$ is time in days (d) between a given day in the initial phase and the day of emergence; $M_{\max }$ is the maximum potential biomass carbon addition rate by the end of the initial phase; $M_{\text {init }}$ is the initial biomass carbon addition rate $\left(\mathrm{g} \mathrm{C} \mathrm{m}^{-2} \mathrm{~d}^{-1}\right)$, estimated based on the initial biomass on the day of emergence, assuming that carbon constitutes $45 \%$ of the biomass; $\tau_{\text {seed }}$ is the time in days (d) between the emergence and the end of the early phase during which the seed stored carbon is utilized; $C_{M}$ and $C_{T}$ are moisture and temperature dependent coefficients (derived using the information given in de Vries et al. (1989); dimensionless).

During rest of the growth cycle after the above initial seedling phase, daily photosynthetic assimilate (accumulated sub hourly photosynthetic carbon) was used as the basis in deriving the daily increments in biomass carbon.

The biomass carbon added on each day was allocated to different plant pools at crop specific growth stages (Fig. 3), set by the growing degree days and the number of days since emergence (Fig. 4; Puckridge, 1972; Taylor et al., 1982; Wells et al., 1986; Yamagata et al., 1987; Gregory and Atwell, 1991; Ritchie et al., 1996; Gregory et al.,1997; Gómez-Macpherson et al., 1998; McMaster and Wilhelm, 1998; Wilhelm, 1998; Heard, 2004). At the end of each day, the carbon in each pool was calculated by subtracting the growth and maintenance respiration (details follow) from the daily biomass carbon allocation; the amount of leaf carbon was used to calculate a daily LAI value (Eq. (3)). Senescence was induced when the leaf respiration exceeded daily leaf growth, causing biomass loss. Following the vegetative phase of growth, further allocation to leaves was significantly reduced during the subsequent reproductive phase of growth (Figs. 3 and 4). The crop was harvested after it reached physiological maturity, allowing some field drying (Fowler, 2002; Neilson et al., 2005). 


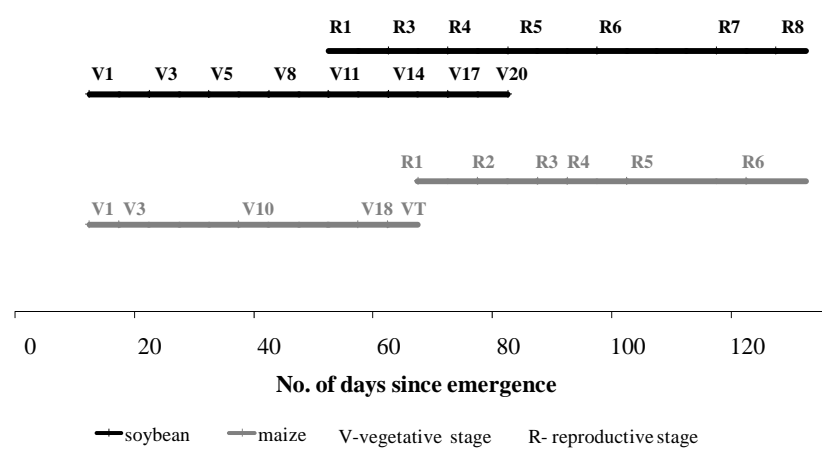

Fig. 3. Growth stages for maize and soybean. Maize: V1V18=vegetative growth stages from single leaf to 18-leaf stage; VT=tasseling; R1-R6=reproductive growth stages; R1=silking; R2=blister; R3=milk; R4=dough; R5=dent; R6=physiological maturity. Soybean: V1-V20=vegetative stages from single leaf to 20-leaf stage; R1-R7- reproductive growth stages; R1=beginning bloom; R2=full bloom; R3=beginning pod; R4=full pod; R5=beginning seed; R6=full seed; R7=beginning maturity; $\mathrm{R} 8=$ full maturity.

$\mathrm{LAI}=C_{\text {leaf }}{ }^{*}{ }^{*} \mathrm{SLA}$

where LAI is leaf area index $\left(\mathrm{m}^{2} \mathrm{~m}^{-2}\right) ; C_{\text {leaf }}$ is the amount of leaf carbon $\left(\mathrm{g} \mathrm{m}^{-2}\right)$; SLA is specific leaf area $\left(\mathrm{m}^{2} \mathrm{~g}^{-1}\right)$.

\section{Estimation of growth and maintenance respiration}

On each day, growth respiration (estimated using the combination of crop-specific growth respiration coefficients for different plant pools) was calculated as a function of biomass carbon allocated to each plant pool. Growth respiration in each pool was the amount of $\mathrm{CO}_{2}-\mathrm{C}$ emitted in the formation of new crop biomass (Eq. (4)):

$R_{g(i)}=\operatorname{alloc}_{(i)}{ }^{*} \operatorname{coeff}_{g(i)}$

where $R_{g(i)}=$ growth respiration $\left(\mathrm{g} \mathrm{CO}_{2}-\mathrm{C} \mathrm{m}^{-2} \mathrm{~d}^{-1}\right) ; i=1-4$ (1=roots; $2=$ leaves; $3=$ =stems; $4=$ products (e.g. flowers and grain); $\operatorname{alloc}_{(i)}=$ daily biomass carbon allocation to each plant pool $\left(\mathrm{g} \mathrm{C} \mathrm{m}^{-2} \mathrm{~d}^{-1}\right)$; coeff ${ }_{g(i)}=$ growth respiration coefficient ( $\mathrm{g} \mathrm{CO}_{2}-\mathrm{Cg}^{-1}$ biomass carbon in the $i$ th pool $\mathrm{d}^{-1}$; Table 1 ).

Maintenance respiration was calculated considering the fraction of the total non-structural carbohydrate and protein carbon (Thornton et al., 1969; Evans et al. 1984; Reekie and Redmann, 1987; Kiniry, 1993; Beauchemin et al., 1997; Allen et al., 1998; Blum, 1998; Brouquisse et al., 1998; Collar and Askland, 2001) within different plant carbon pools on each day, considering a temperature dependent $Q_{10}$ function with a base temperature of $25^{\circ} \mathrm{C}$. In deriving the maintenance respiration coefficients in terms of carbon, the carbon percentage in dry weight was considered as $45 \%$ (Buchanan and King, 1993; Bolinder et al., 1997; Vanotti et al., 1997; Burgess et al., 2002; Torbert et al., 2004). Carbon emission as $\mathrm{CO}_{2}-\mathrm{C}$ in maintenance respiration for each plant pool was

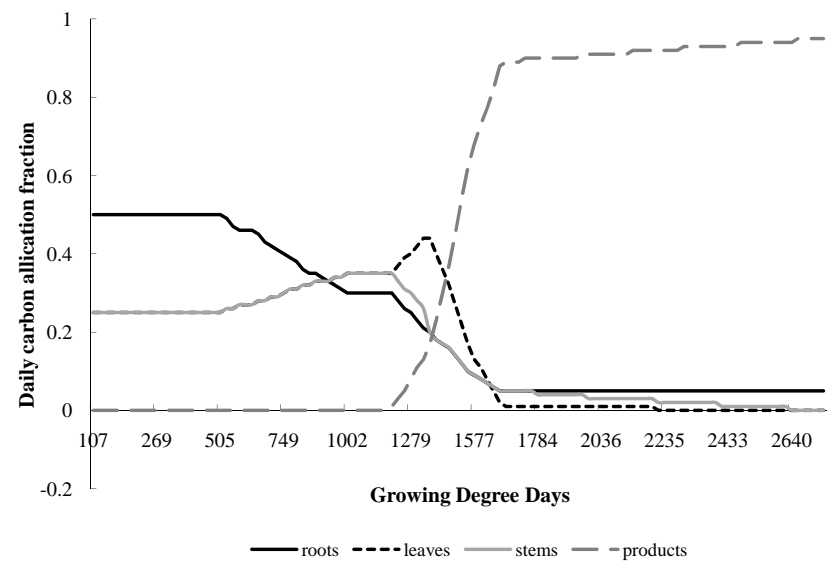

Fig. 4. Carbon allocation scheme for maize.

predicted from the carbon in each plant pool and maintenance respiration coefficients specific to each pool and crop type (Table 1; Eq. (5)):

$R_{m(i)}=W_{(i)} * \operatorname{coeff}_{m(i)} * f_{\mathrm{TNC}, p(i)} * Q_{10}(T-20) / 10$

where $R_{m}=$ maintenance respiration $\left(\mathrm{g} \mathrm{CO}_{2}-\mathrm{C} \mathrm{m} \mathrm{m}^{-2} \mathrm{~d}^{-1}\right)$; $i=1-4 \quad$ (1=roots; $\quad 2=$ leaves; $\quad 3=$ stems; $\quad 4=$ grain); $W=$ cumulative carbon in the $i$ th pool $\left(\mathrm{g} \mathrm{C} \mathrm{m}^{-2} \mathrm{~d}^{-1}\right)$; coeff ${ }_{m(i)}=$ maintenance respiration coefficient $\left(\mathrm{gCO}_{2}-\right.$ $\mathrm{C}$ emitted $\mathrm{g}^{-1}$ carbon in the $i$ th pool $\mathrm{d}^{-1}$; Table 1 ); $f_{\mathrm{TNC}, p(i)}=$ fraction of carbon in non structural carbohydrates (TNC) and proteins of the $i$ th pool (this was estimated considering that TNC have $45 \%$ carbon and proteins have $53 \%$ carbon (Hopkins et al., 1929; de Vries et al., 1989)); $Q_{10}=Q_{10}$ coefficient (i.e. 2.0 (Norman and Arkebauer, 1991; Gourdriaan and Van Laar, 1994)); $T$ =temperature $\left({ }^{\circ} \mathrm{C}\right)$.

\subsubsection{Evaluation of the model performance}

The performance of SiBcrop was evaluated by comparing the observed and predicted $\mathrm{CO}_{2}$ fluxes and LAI at three AmeriFlux eddy covariance flux tower sites with crops: Bondville, Illinois (IL), and Mead, Nebraska (NE), and ARM-SGP site, Oklahoma (OK).

The Bondville site (latitude 40.0061000; longitude -88.2918667; elevation $300 \mathrm{~m}$ ) is located in central Illinois and has operated since August 1996 (Meyers and Hollinger, 2004). It has rainfed, no-till maize and soybean crops grown in rotation (maize in odd numbered years and soybean in even numbered years). The Mead site (latitude 41.1796670; longitude -96.4396460; elevation $363 \mathrm{~m}$ ) is located in Saunders county in eastern Nebraska (Suyker et al., 2004). Mead has both irrigated and rainfed sites, and only the rainfed site was chosen for this study. This site has operated since 2001 also with rainfed no-till maize and soybean grown in rotation. At these sites, maize plants grow to a height of 2.5 (Mead, $\mathrm{NE}$ ) to $3.0 \mathrm{~m}$ (Bondville, IL), and soybean plants grow to a height of about $0.9 \mathrm{~m}$. 


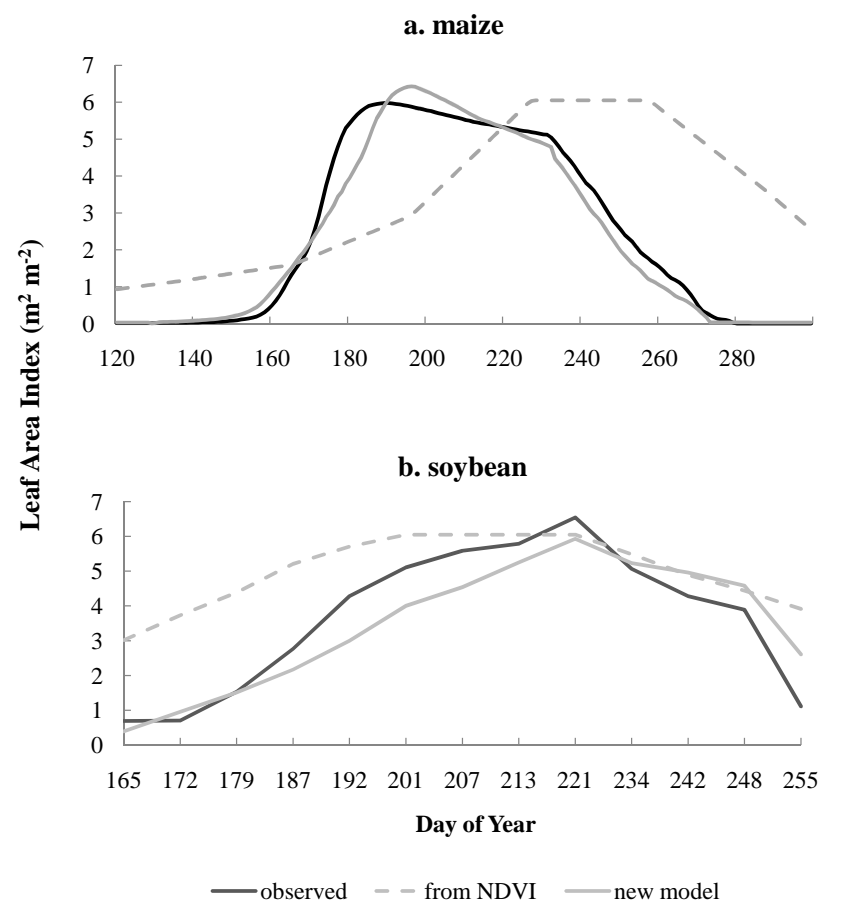

Fig. 5. Leaf Area Index (LAI) of crops in rotation in Bondville. (a) maize in 1999; (b) soybean in 2000. LAI from observed, new model, and NDVI (i.e. original SiB). The drop of LAI towards the end of the growing season represents the field drying and harvest events.

The ARM-SGP site (latitude 36.60499954; longitude -97.48840332; elevation 300-320 m), which has been active since 1999, is located in Grant county, Oklahoma. This site has winter wheat as the main crop, in addition to some pasture and summer crops such as maize, soybean, and sorghum (Fischer et al., 2007). For the current study, the years which exclusively had the winter wheat crop with recorded observed $\mathrm{CO}_{2}$ flux measurements (i.e. end of 2002-2004) were chosen to evaluate the performance of SiBcrop for wheat. Wheat plants at this rain fed site grow to a height of about $0.5 \mathrm{~m}$.

SiBcrop could be run at any spatial resolution, with the availability of suitable weather data. For this study we used a time step of $30 \mathrm{~min}$. Each eddy covariance site was simulated as a single homogeneous spatial unit for periods with observed data, using meteorological forcing from 6-hourly NCEP-DOE Reanalysis 2 (Kalnay et al., 1996) weather data, and crop information as given in the AmeriFlux website. Soil texture was derived from the NRCS State Soil Geographic (STATSGO) database. For the control runs with original $\mathrm{SiB}$, AVHRR NDVI data interpolated from monthly Global Inventory of Modeling and Mapping Studies, version "g" (GIMMSg; Tucker et al., 2005) data were used in estimating LAI and fPAR.
Sub hourly, diurnal, and annual net ecosystem exchange (NEE; i.e. respiration-photosynthesis), LAI, and biomass values predicted by SiBcrop for each site were compared against observed data. The annual NEE cycles were formulated based on the monthly means derived from sub hourly fluxes. Seasonality and the year-to-year variation in the carbon fluxes, LAI, and biomass were compared and studied considering the presence of single crop (winter wheat) and crop rotation (i.e. alternating maize and soybean crops as at Bondville and Mead sites) in the field. Statistical evaluation and comparisons of the predicted fluxes and LAI from control runs and SiBcrop against the observed data were made using simple linear regression analyses and appropriate statistical criteria (i.e. R-sq and root mean square error (RMSE)). Predicted biomass by SiBcrop were also compared against the observed biomass at the sites, using the same criteria.

\section{Results and discussion}

\subsection{SiBcrop simulations for summer crops (maize and soybean)}

SiBcrop was able to predict the planting and harvest events and the changing phases within crop development and growth cycle, in terms of LAI, biomass carbon, and carbon fluxes for these sites, with more accuracy than the original $\mathrm{SiB}$.

The maximum LAI predicted for maize in different years ranged between $5.0 \mathrm{~m}^{2} \mathrm{~m}^{-2}$ and $6.3 \mathrm{~m}^{2} \mathrm{~m}^{-2}$ at Bondville, and between $5.0 \mathrm{~m}^{2} \mathrm{~m}^{-2}$ and $6.0 \mathrm{~m}^{2} \mathrm{~m}^{-2}$ at Mead. The maximum LAI predicted for soybean ranged between 4.6 and $5.7 \mathrm{~m}^{2} \mathrm{~m}^{-2}$ at Bondville, and between 3.9 and $5.3 \mathrm{~m}^{2} \mathrm{~m}^{-2}$ at Mead. These predicted ranges were acceptable based on the observed ranges at these two sites, except that the model over predicted the maximum LAI observed for Mead during certain soybean years. For instance, in 2002, the maximum LAI observed at Mead site was 3.0, while the mean LAI predicted by SiBcrop was 3.9. Compared to the LAI estimates based on NDVI in original $\mathrm{SiB}, \mathrm{SiBcrop}$ predicted LAI values that had better synchrony with the observed LAI in the field (Fig. 5). In 1999, the NDVI-based LAI was higher at the initial phase of the growing season and peaked at a later time than the LAI observed in the field and that predicted by SiBcrop. This pattern of variation in the remotely sensed NDVI could be attributed to the mixed pixels (in the early phase), cloud contamination and the interpolation scheme, as described before. The regression between NDVI-based LAI in control runs and observed data in 1999 (Fig. 5) had much lower R-sq (0.14) and higher RMSE (2.22) compared to SiBcrop versus observed data $(\mathrm{R}-\mathrm{sq}=0.97$ and $\mathrm{RMSE}=0.43)$. R-sq and RMSE values for overall comparisons of original $\mathrm{SiB}$ and $\mathrm{SiBcrop}$ against the observed data at different sites are given in Table 2 . 
In addition to the prognostic equations in $\mathrm{SiB}, \mathrm{SiBcrop}$ predicted biomass carbon in different plant pools, LAI, etc., from the phenology scheme by the end of each day. The variation in carbon in different plant pools until physiological maturity at Bondville site is illustrated in Fig. 6. Among the different plant pools, the highest amount of carbon was observed for the products, and the total biomass (both aboveand below ground) estimated for maize was much higher than that for soybean (Table 3). Maize in both Bondville and Mead sites had 55-60\% of the total carbon in the products at harvest (grains, cobs, and husks), while roots, leaves and stems shared the remainder of the carbon. By converting the biomass carbon to biomass (by multiplying by 2.2) and considering a grain weight of about $80 \%$ of the total products at harvest (Heard, 2004), we estimated a Harvest Index that ranged between 0.52 and 0.55 , for maize at both sites. These results are in agreement with the reported range (i.e. 0.4-0.58) by Prince et al. (2001) and Heard (2004; Harvest Index 0.54). The average root:shoot ratio estimated at harvest across the maize years was 0.18 . This was similar to the average root:shoot ratio observed by Anderson (1988).

The aboveground and total biomass predicted for soybean at Mead was slightly higher compared to Bondville (Table 3). The predicted biomass of products (seeds and pods) at harvest ranged between $44-49 \%$ and $38-43 \%$ of the total soybean biomass (across different years) at Bondville and Mead, respectively. Considering that the $70 \%$ of the product at harvest (i.e. beans and pods together) was beans (Hanway and Weber, 1971a, 1971b; Buyanovsky and Wagner, 1986), we estimated a Harvest Index that ranged between 0.37 and 0.41 during the years with soybean. This Harvest Index range fell within the range (i.e. 0.37-0.45) reported by Rao et al. (2002) and that reported by Spaeth et al. (1984; Harvest Index range 0.25-0.6)). The estimated average root:shoot ratio soybean at harvest was 0.18 . This ratio fell within the range (of 0.140.19) observed by Allmaras et al. (1975), and it was slightly higher than the value of 0.15 observed by Silvius et al. (1977) for non-stressed plants, and the highest value (i.e. 0.126), among the values reported by Taylor et al. (1982).

When the biomass carbon was converted to the biomass in each plant pool, we found that the model predicted values for both crops were acceptable based on the values found in certain past studies (Taylor et al., 1982; Ritchie et al., 1996; Heard, 2004). For instance, the average biomass carbon predicted by SiBcrop for maize leaves, stems, and products at harvest for Mead site were 103.5, 136.7, and $487.1 \mathrm{~g} \mathrm{C} \mathrm{m}^{-2}$, respectively. Assuming that carbon is $45 \%$ of the total dry weight, the carbon content in maize leaves, stems, and products according to Heard (2004) were 92.2, 120.3 , and $476.7 \mathrm{~g} \mathrm{C} \mathrm{m}^{-2}$, respectively. Similarly, the average biomass carbon predicted by SiBcrop for soybean roots, leaves, stems, and products at harvest for Bondville site were $58,44.5,115.4$, and $186.2 \mathrm{~g} \mathrm{C} \mathrm{m}^{-2}$, respectively. Calculated average carbon (i.e. $45 \%$ of dry weight) for rain fed soybean leaves, stems, and products based on the dry weights reported
Table 2. Results (R-sq and RMSE) for the comparisons of control runs and SiBcrop against the observed data at Bondville and Mead.

\begin{tabular}{|c|c|c|c|c|}
\hline Variable & Site & $\begin{array}{l}\text { Regression } \\
\text { (against the } \\
\text { observed data) }\end{array}$ & $\mathrm{R}-\mathrm{sq}$ & RMSE \\
\hline \multirow[t]{16}{*}{$\begin{array}{l}\text { NEE } \\
\left(\mu \mathrm{mol} \mathrm{m}^{-2} \mathrm{~s}^{-1}\right)\end{array}$} & \multirow[t]{8}{*}{ Bondville } & $\begin{array}{l}\text { All years } \\
\text { (maize and soybean } \\
\text { years combined) }\end{array}$ & & \\
\hline & & Control runs & $0.30^{* *}$ & 7.28 \\
\hline & & $\begin{array}{l}\text { SiBcrop } \\
\text { Maize years }\end{array}$ & 0.58 & 5.42 \\
\hline & & Control runs & $0.35^{* *}$ & 7.78 \\
\hline & & SiBcrop & 0.68 & 6.68 \\
\hline & & Soybean years & & \\
\hline & & Control runs & 0.24 & 4.83 \\
\hline & & SiBcrop & 0.36 & 3.58 \\
\hline & \multirow[t]{8}{*}{ Mead } & All years & & \\
\hline & & Control runs & $0.52^{* *}$ & 5.25 \\
\hline & & $\begin{array}{l}\text { SiBcrop } \\
\text { Maize years }\end{array}$ & 0.70 & 5.88 \\
\hline & & Control runs & $0.60^{* *}$ & 5.1 \\
\hline & & SiBcrop & 0.72 & 7.33 \\
\hline & & Soybean years & & \\
\hline & & Control runs & 0.51 & 6.82 \\
\hline & & SiBcrop & 0.57 & 3.49 \\
\hline \multirow{12}{*}{$\begin{array}{l}\text { LAI } \\
\left(\mathrm{m}^{2} \mathrm{~m}^{-2}\right)\end{array}$} & \multirow[t]{6}{*}{ Bondville } & Maize years & & \\
\hline & & Control runs & 0.41 & 1.68 \\
\hline & & SiBcrop & 0.84 & 0.89 \\
\hline & & Soybean years & & \\
\hline & & Control runs & 0.45 & 1.55 \\
\hline & & SiBcrop & 0.67 & 1.23 \\
\hline & \multirow[t]{6}{*}{ Mead } & Maize years & & \\
\hline & & Control runs & 0.35 & 2.11 \\
\hline & & SiBcrop & 0.72 & 1.27 \\
\hline & & Soybean years & & \\
\hline & & Control runs & 0.60 & 0.72 \\
\hline & & SiBcrop & 0.84 & 0.69 \\
\hline \multirow{6}{*}{$\begin{array}{l}\text { Biomass* } \\
\left(\mathrm{g} \mathrm{C} \mathrm{m}^{-2}\right)\end{array}$} & \multirow[t]{3}{*}{ Bondville } & All years & 0.90 & 85.84 \\
\hline & & Maize years & 0.89 & 103.2 \\
\hline & & Soybean years & 0.85 & 49.7 \\
\hline & \multirow[t]{3}{*}{ Mead } & All years & 0.98 & 29.76 \\
\hline & & Maize years & 0.98 & 32.24 \\
\hline & & Soybean years & 0.97 & 23.61 \\
\hline
\end{tabular}

* total aboveground biomass carbon predicted by SiBcrop against the observed data; ** Slope coefficient $(\beta)$ was $\leq 0.5$ in the regression equation, suggesting that the predicted values change by approximately half a unit, per unit change of the observed values (making the r-sq meaningless for a 1:1 relationship).

by Taylor et al. (1982) were 35.3, 111.0 and $180.0 \mathrm{~g} \mathrm{C} \mathrm{m}^{-2}$, respectively. Compatibility of the predicted biomass values by $\mathrm{SiBcrop}$ were further tested by the comparisons against the measured total aboveground biomass (converted to carbon) for the two sites. The R-sq and RMSE values relevant to biomass comparisons are given in Table 2. Although the biomass carbon values in both crops were closely 
a. maize
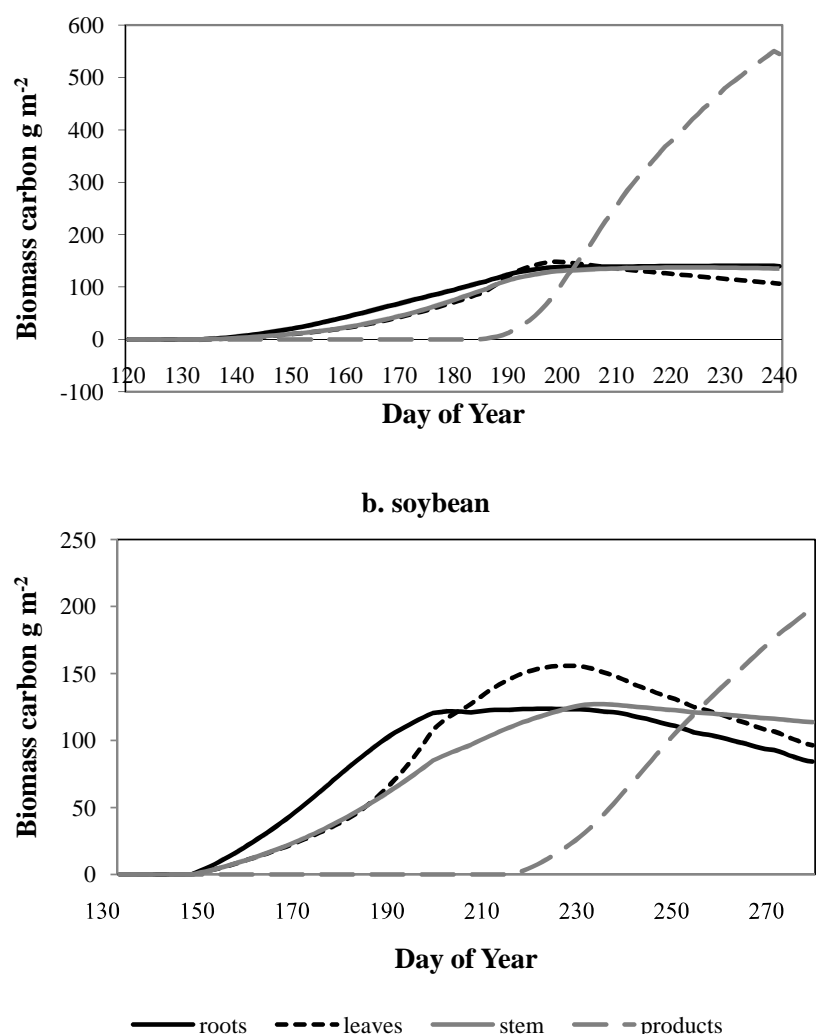

Fig. 6. Biomass carbon predicted for Bondville by the SiBphenology coupled model (i.e. SiBcrop) for different pools by physiological maturity; (a) maize in 1999, and (b) soybean in 1998.

simulated, predicted values were slightly higher than the observed biomass at Mead site and mixed results were found for Bondville (Fig. 7). The growth in SiBcrop is dependent on variation in weather and the assimilation, which is limited by enzyme kinetics (Farquhar et al., 1980) and stomatal physiology (Collatz et al., 1991, 1992). The model does not capture any impact from herbivory or weed control, etc. Thus the slight deviation of the predicted values from observed data might be indicative of the exact field conditions which might also reflect the latter. Since the current version of SiBcrop is based on the assumption that the crop plants are not nutrient limited, it also does not capture any impact from fertilizer application.

Seasonal and interannual variation in carbon fluxes of cropland systems were relatively poorly predicted in the control simulations (Fig. 8a; Table 2). However, SiBcrop clearly showed the rotation of maize (C4) and soybean (C3) in the field, with maize having a much higher carbon uptake. SiBcrop also better predicted the seasonality associated with the crop growth cycle (Fig. 8b; Table 2). Similar results were observed for Mead, as well (Fig. 11b; Table 2). With original $\mathrm{SiB}$, there was poor synchrony between the NEE curves of
Table 3. Average predicted biomass.

\begin{tabular}{llll}
\hline \multirow{2}{*}{ Crop } & site & \multicolumn{2}{c}{ Biomass carbon $\mathrm{g} \mathrm{m}^{-2}$} \\
& & Total & Aboveground \\
\hline Maize & Bondville & $931.3 \pm 31.2$ & $790.7 \pm 22.4$ \\
& Mead & $852.1 \pm 18.8$ & $727.2 \pm 4$ \\
Soybean & Bondville & $404.2 \pm 74$ & $346.1 \pm 60$ \\
& Mead & $435 \pm 77.2$ & $360 \pm 64.1$ \\
Wheat & ARM-SGP & $375.3 \pm 18.3$ & $292.3 \pm 12.4$ \\
\hline
\end{tabular}

the predicted and observed data (Figs. 8a and 11a; Table 2). However, with further modification of certain $\mathrm{SiB}$ parameter values (Table 1), and by using predicted phenology, we were able to improve the model performance significantly. Considering the presence of only maize during odd numbered years (as in the field) and increase of $\mathrm{V}_{\max }$ and high temperature inhibition for maize, allowance of removal of harvest, and incorporating new phenology scheme in SiBcrop helped improve the magnitude of predicted NEE and the compatibility with observed data in the field for maize (Figs. 9b and 11c; Table 2). Similarly, considering the presence of only soybean in the field during even numbered years and predicting carbon fluxes through LAI derived from the phenology scheme, substantially improved the synchrony and compatibility of the predicted values with observed NEE for soybean (Fig. 10; Table 2). Overall, LAI, biomass, and NEE predicted by SiBcrop had relatively higher R-sq and lower RMSE values compared to the control runs. The new phenology scheme within SiBcrop helped better predict the magnitude and seasonality of the carbon fluxes and LAI, compared to the control simulation.

The highest NEE values predicted by SiBcrop for maize were more than $80 \%$ of the observed values in the field. The maximum predicted carbon drawdown by maize as represented in NEE, ranged between 15 and $20 \mu \mathrm{mol} \mathrm{m}^{-2} \mathrm{~s}^{-1}$ in the annual cycles based on monthly averages, and $\sim 60 \mu \mathrm{mol} \mathrm{m}^{-2} \mathrm{~s}^{-1}$ at sub hourly scale (Figs. 8 and 9). In the diurnal cycle, the highest predicted NEE occurred between 12:00 and 03:00 p.m. NEE was positive before $\sim$ 07:00 a.m., since it was dominated by respiration (Figs. $8 \mathrm{c}$ and $11 \mathrm{~d}$ ).

The predicted carbon fluxes for maize were mostly comparable to the observed fluxes, and occasionally there were outliers in the observed data as well, which were more noticeable in the data at sub hourly time scale.

The maximum NEE observed and predicted by SiBcrop for the soybean years was $\sim 5 \mu \mathrm{mol} \mathrm{m}^{-2} \mathrm{~s}^{-1}$ in the annual cycles based on monthly averages (Fig. 8b), and the maximum values at sub hourly scale were between 15 and $20 \mu \mathrm{mol} \mathrm{m}^{-2} \mathrm{~s}^{-1}$ in both sites; however, observed maximum was mostly between 20 and $30 \mu \mathrm{mol} \mathrm{m}^{-2} \mathrm{~s}^{-1}$ at sub hourly scale (Fig. 10). Results showed the lower carbon uptake due 


\section{a. 2001}
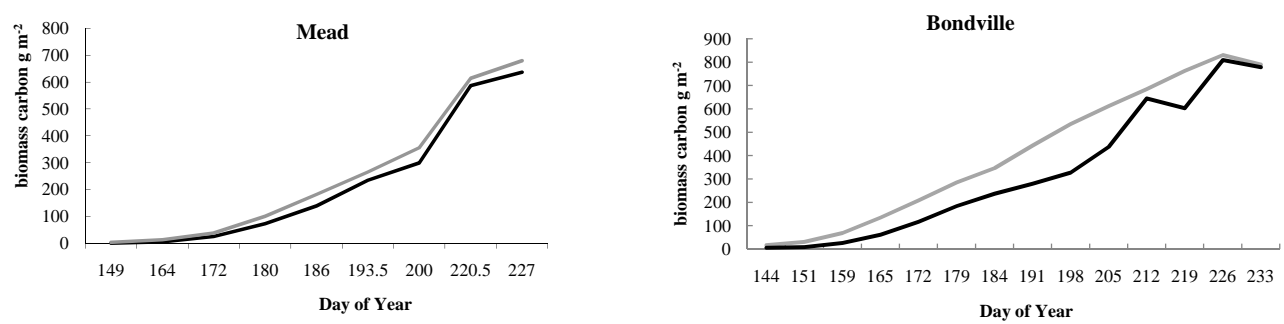

b. 2002
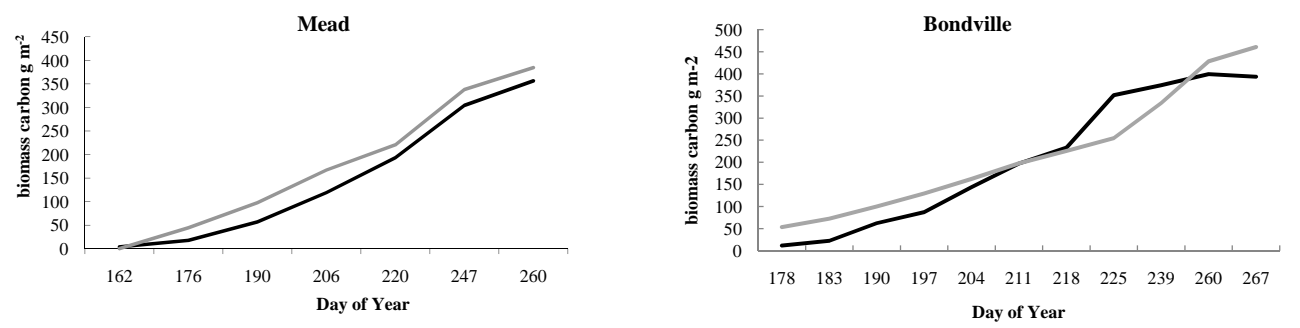

—observed - predicted

Fig. 7. Observed and predicted total aboveground biomass carbon at Mead and Bondville during a maize year (a) 2001 and a soybean year (b) 2002 .
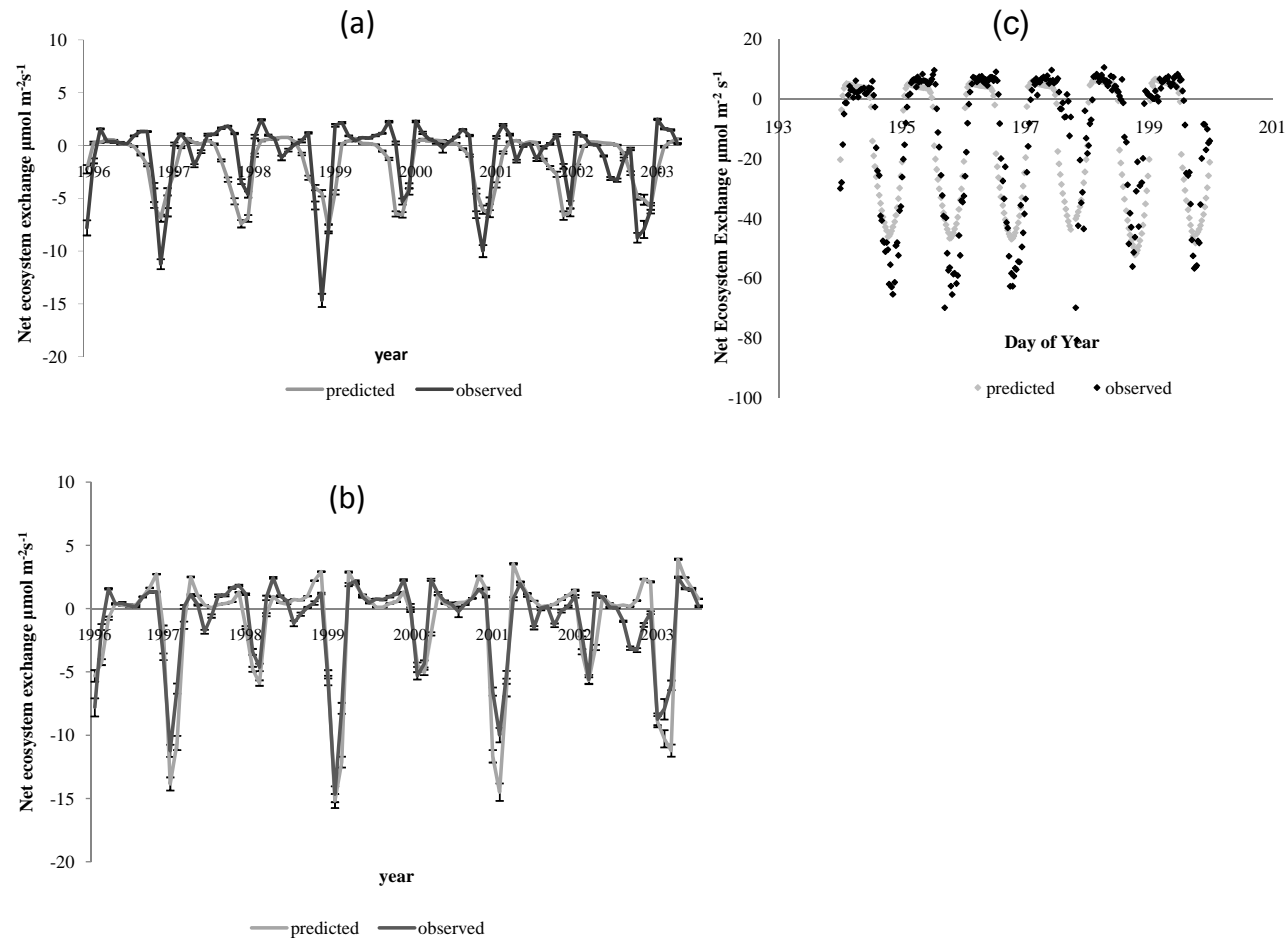

Fig. 8. Monthly means of Net Ecosystem Exchange (NEE) for Bondville site; (a) observed and predicted NEE from SiB before any modification (control); (b) simulation from the new model (i.e. SiB using LAI produced from phenology models for maize (odd years) and soybean (even years); bottom); (c) diurnal pattern of variation of sub hourly NEE at Bondville in mid July 1999. 
a. Original model

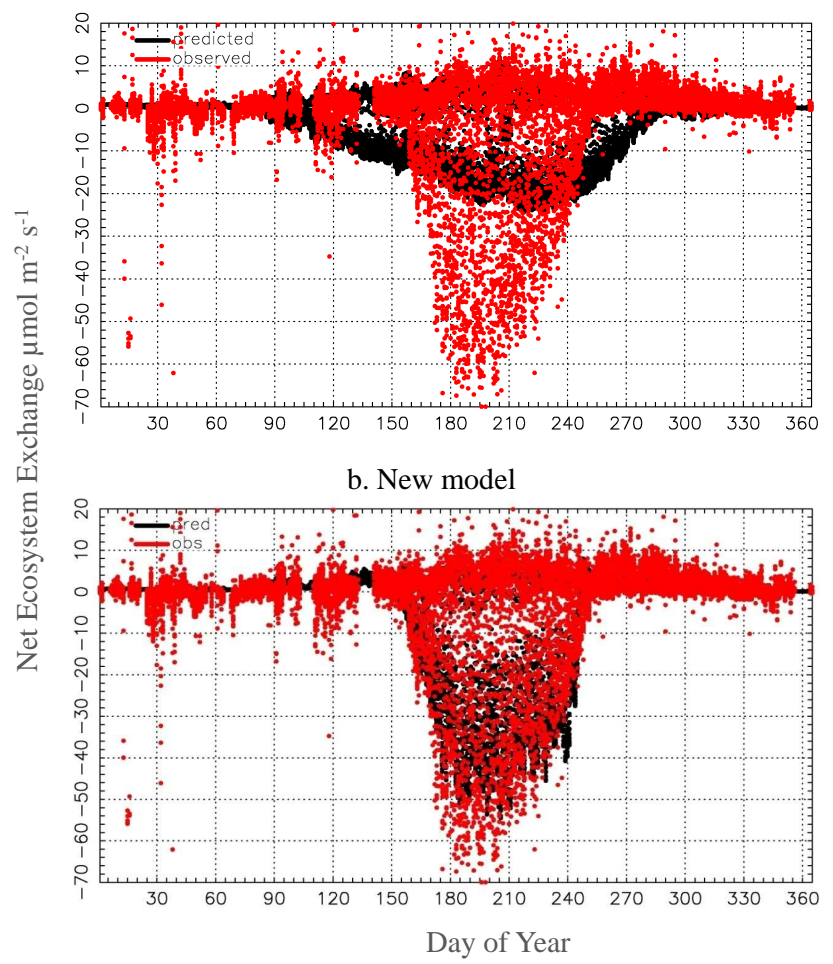

Fig. 9. Predicted and observed sub hourly fluxes for the Bondville site in a maize year (1999).

to lower photosynthetic efficiency in soybean, compared to maize, although soybean has a higher $\mathrm{V}_{\max }$. The predicted NEE values for soybean were still less than the observed values.

\subsection{Simulations for winter wheat}

The average maximum Leaf Area Index predicted for winter wheat at ARM-SGP site was $3.0 \mathrm{~m}^{2} \mathrm{~m}^{-2}$, and predicted LAI was within $0.5 \mathrm{~m}^{2} \mathrm{~m}^{-2}$ compared to the observed LAI (Fig. $12 \mathrm{~b}$ ). The predicted LAI had similar variation and good synchrony with the observed LAI.

The sub hourly predicted NEE for wheat followed a similar pattern of variation. However, the maximum observed diurnal NEE was mostly between $20-30 \mu \mathrm{mol} \mathrm{m}^{-2} \mathrm{~s}^{-1}$, while the maximum predicted NEE was between 15 and $20 \mu \mathrm{mol} \mathrm{m}^{-2} \mathrm{~s}^{-1}$ (Fig. 12a and 12d); the R-sq for the regression between observed and predicted NEE was 0.4 and the RMSE was $6.3 \mu \mathrm{mol} \mathrm{m}^{-2} \mathrm{~s}^{-1}$. When the annual cycles with monthly averages were taken, the model yielded slightly higher NEE compared to the observed, although the same pattern of variation could be seen with respect to seasonality. Carbon uptake in early vegetative stages was relatively low from planting towards the end of the year until the spring green-up in the following year, during which period the plants also undergo vernalization (i.e. cold requirement

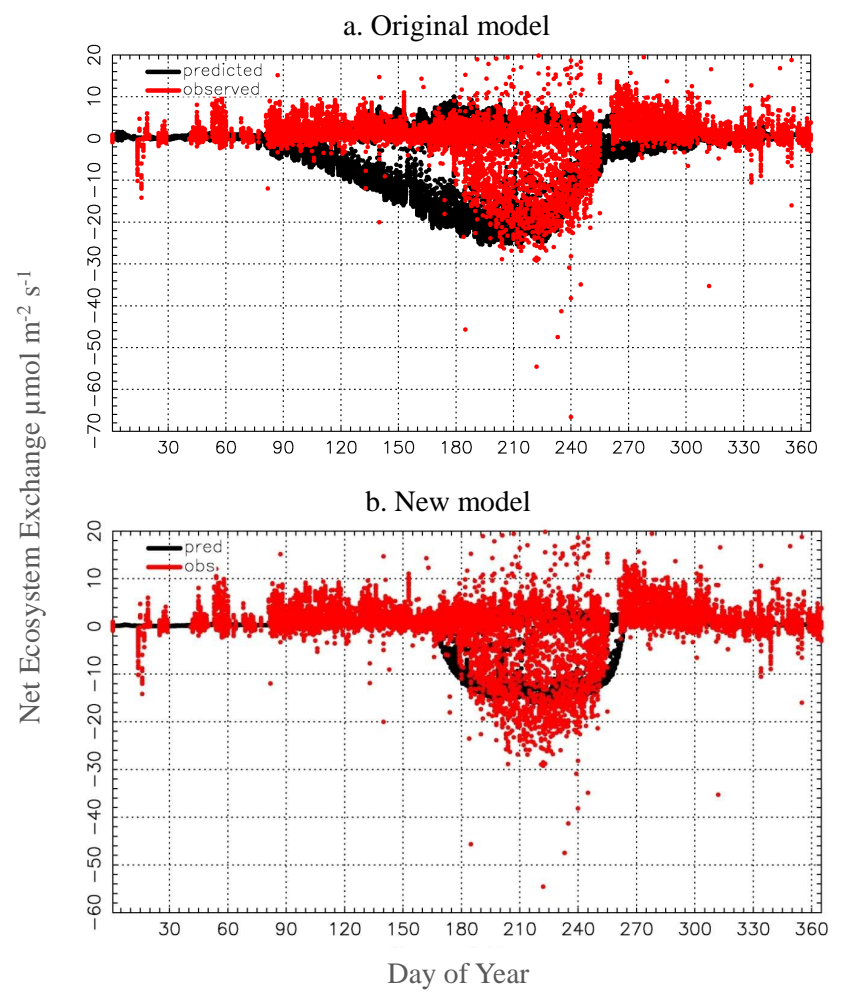

Fig. 10. Predicted and observed sub hourly fluxes for the Bondville site in a soybean year (1998).

for the transition from vegetative to reproductive growth; Bierhuzen, 1973; Brooking, 1996; Ritchie, 1991). Rapid growth and higher carbon uptake (i.e. NEE) was observed after the spring green-up in the following year (Fig. 12c).

According to SiBcrop simulations, the average total aboveground biomass carbon for winter wheat was $292 \mathrm{~g} \mathrm{~m}^{-2}$ (Table 3), which was consistent with the average observed in the field, $270 \mathrm{~g} \mathrm{~m}^{-2}$, where the typical measurement error was about 5\%. The average harvest index based on $\mathrm{SiBcrop}$ runs was 0.41 , while the recorded harvest indices for the crop usually ranged between 0.32 and 0.43 (Sharma et al., 1987; Gent and Kyomoto, 1989; Prince et al., 2001). The total biomass carbon averaged over the years with winter wheat was $375 \mathrm{~g} \mathrm{C} \mathrm{m}^{-2}$. Considering a $45 \%$ carbon in dry matter, this converts to $834 \mathrm{~g} \mathrm{~m}^{-2}$ dry matter. This falls within the range of total dry matter weights given by Wilhelm (1998) for winter wheat under different tillage and nitrogen fertilization rates (i.e. between 636 and $848 \mathrm{~g} \mathrm{~m}^{-2}$ dry matter).

Overall, SiBcrop showed improved performance in predicting carbon fluxes on croplands, compared to the control simulations with original $\mathrm{SiB}$. However, $\mathrm{SiB}$ crop still seems to slightly underpredict the $\mathrm{CO}_{2}$ uptake at sub hourly scale, mostly by $\mathrm{C} 3$ crops, although a similar pattern of variation and seasonality was seen as observed in the field. So far we have developed these phenology schemes for three main 

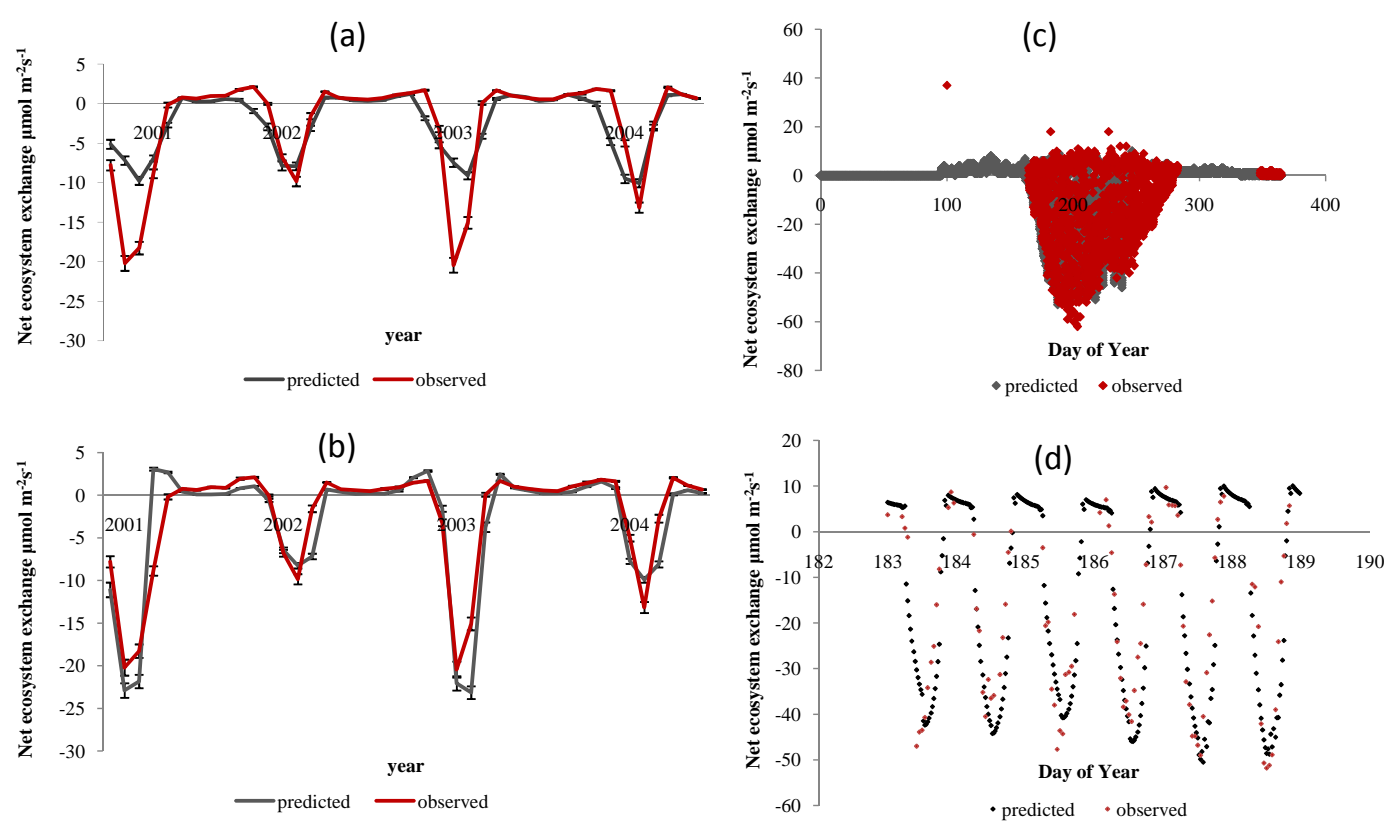

Fig. 11. Evaluation of predicted NEE against the observed data at a rainfed site in Mead, NE with maize and soybean in rotation. (a) monthly comparison with original model; (b) monthly comparision with new model; (c) sub hourly comparison with new model in 2001; (d) diurnal variation in the sub hourly NEE in early July in 2001.
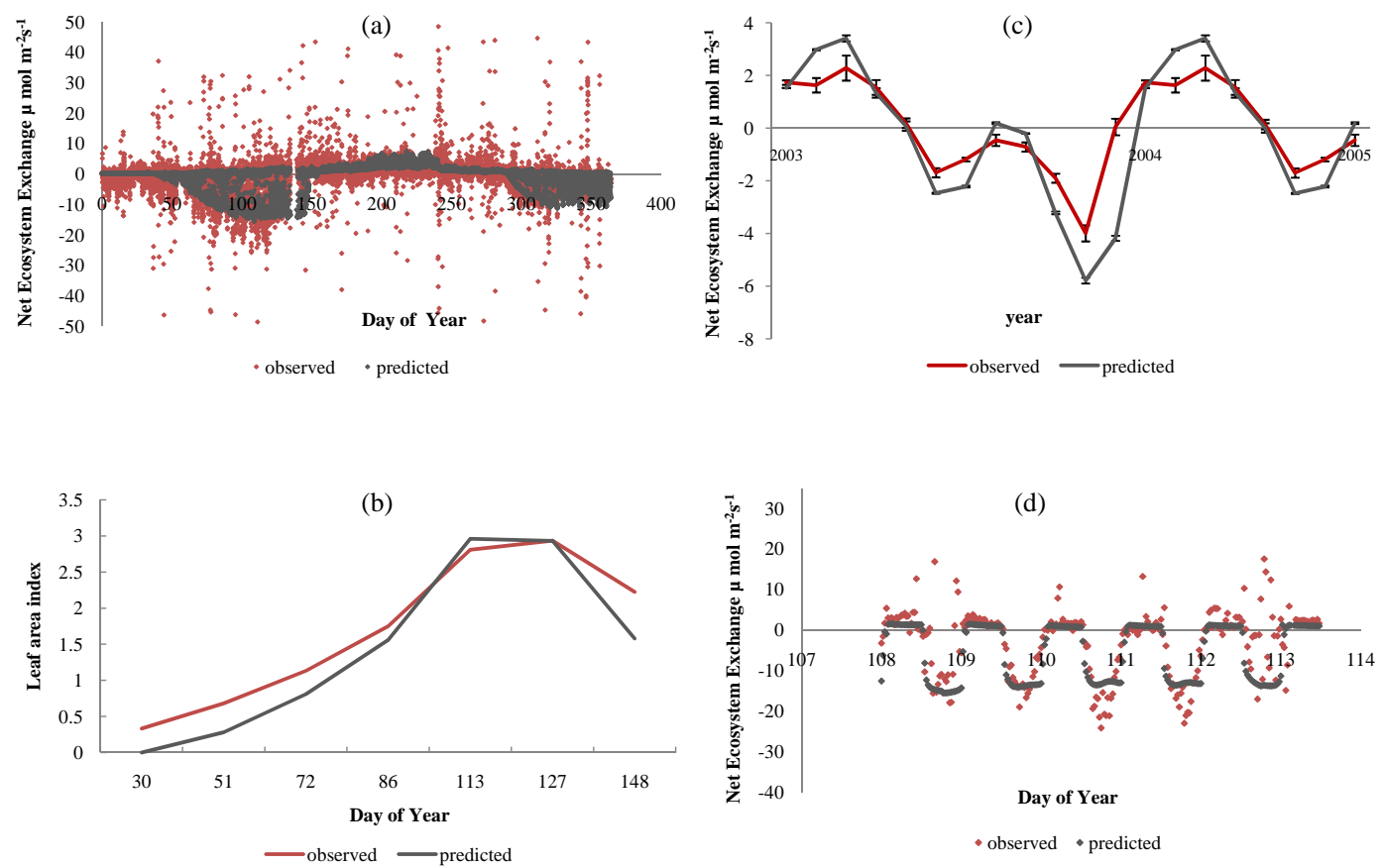

Fig. 12. Evaluation of SiBcrop performance for wheat at ARM-SGP site by comparison of observed and predicted data in 2003: (a) subhourly NEE; (b) LAI; (c) monthly means of NEE; (d) diurnal variation of sub hourly NEE from 18-23 April.

C3 and C4 crops, and our aim is to expand it to other major crops. The current version of SiBcrop was developed to be used within the continental United States, and model evaluation in this particular study was done using three Amer-
iFlux eddy covariance flux tower sites in the US midwest. However, we plan on wider use of the model, and thus further model testing using more sites at locations with different climates and weather variability is warranted. We plan to 
extend such applicability by adding more crop types and additional sites globally. In the future, SiBcrop will be coupled with the Regional Atmospheric Modeling System (RAMS; Pielke et al., 1992; Corbin et al., 2008), a mesoscale meteorological (non-hydrostatic) model, to estimate time-varying exchanges of carbon, water, and energy, and the performance of this regional modeling system is planned to be tested against the observations at a variety of spatial scales.

\section{Conclusions}

The phenology and physiology scheme we developed was simple and detailed enough to predict LAI values to be used within SiB. LAI and NEE produced by SiBcrop for maize, which is a crop with $\mathrm{C} 4$ physiology, were closer in value and had better synchrony with the observed data in the field, compared to the original SiB model in which LAI (and thus carbon flux estimation) were based on the remotely sensed NDVI. Although the same trend was obvious for the C3 crops, soybean and wheat, the maximum sub hourly NEE predicted for soybean was 20-30\% lower than the maximum NEE observed in the field.

Since SiB's complex, process-based equations, parameters, and stress factors, etc., are involved in the derivation of daily carbon and energy fluxes, such a straight forward and relatively simple phenology and physiology scheme seemed to work well in reaching our objective (i.e. to improve the prediction of carbon fluxes from croplands). The overall validity of the phenology scheme was further confirmed by the LAI and biomass data from field observations and past studies.

Overall, compared to the control, $\mathrm{SiBcrop}$ better predicted spring onset of growth (i.e. prediction of planting dates and the crop growth following spring onset), which improved the estimate of $\mathrm{CO}_{2}$ uptake, especially by maize. The advantage of the new phenology scheme within SiBcrop includes the prediction of biomass which can be evaluated against crop yields, realistic treatment of fine-scale heterogeneity of agro ecosystems, and eventual prediction of future fluxes, for which no satellite data are available.

Acknowledgements. This research was supported by the National Institute for Climate Change Research (NICCR), under Contract No MTU 050516Z14, and the Department of Energy (DoE) under Contract Nos DE-FG02-06ER64317 and DE-AC02-05CH11231. The winter wheat data were collected and made available through the US DoE as part of the Atmospheric Radiation Measurement Program. We would like to thank Joe Berry, Jim Collatz, Chris Williams, Lingxiao Zhang, and Steve Williams for their support on this work.

Edited by: E. Falge

\section{References}

Ainsworth, E. A., Rogers, A., Nelson, R., and Long, S. P.: Testing the "source-sink" hypothesis of down-regulation of photosynthesis in elevated $\left[\mathrm{CO}_{2}\right]$ in the field with single gene substitutions in Glycine max, Agr. Forest Meteorol., 122, 85-94, 2004.

Allen, L. H., Bisbal, E. C., and Boote, K. J.: Nonstructural carbohydrates of soybean plants grown in subambient and superambient levels of $\mathrm{CO}_{2}$, Photosynth. Res., 56, 143-155, 1998.

Allmaras, R. R., Nelson, W. W., and Voorhees, W. B.: Soybean and corn rooting in southwestern Minnesota: II. Root distribution and related water intake, Soil Sci. Soc. Am. Pro., 39, 771-777, 1975.

Anderson, E. L.: Tillage and $\mathrm{N}$ fertilization effects on maize root growth and root: shoot ratio, Plant Soil, 108, 245-251, 1988.

Arora, V. K.: Simulating energy and carbon fluxes over winter wheat using coupled land surface and terrestrial ecosystem models, Agr. Forest Meteorol., 118, 21-47, 2003.

Baigorria, G. A., Jones, J. W., Shin, D.-W., Mishra, A., and O'Brien, J. J.: Assessing uncertainties in crop model simulations using daily bias-correlated Regional Circulation Model outputs, Clim. Res., 34, 211-222, 2007.

Baker, I. T., Denning, A. S., Hanan, N., Prihodko, L., Vidale, P. L., Davis, K., and Bakwin, P.: Simulated and observed fluxes of sensible and latent heat and $\mathrm{CO}_{2}$ at the WLEF-TV Tower using SiB2.5, Glob. Change Biol., 9, 1262-1277, 2003.

Baker, I. T., Denning, A. S., Prihodko, L., Schaefer, K., Berry, J. A., Collatz, G. J., Suits, N. S., Stockli, R., Philpott, A., and Leonard, O.: Global Net Ecosystem Exchange (NEE) of CO2, available at: http://www.daac.ornl.gov/, 2008.

Beauchemin, K. A., Rode, L. M., and Yang, W. Z.: Effects of nonstructural carbohydrates and source of cereal grain in high concentrate diets of dairy cows. J. Dairy Sci., 80, 1640-1650, 1997.

Bernacchi, C. J., Morgan, P. B., Ort, D. R., and Long, S. P.: The growth of soybean under free air [CO2] enrichment (FACE) stimulates photosynthesis while decreasing in vivo Rubisco capacity, Planta, 220, 434-446, 2005.

Betts, R.: Integrated approaches to climate-crop modelling: needs and challenges. Philos. T. R. Soc. B, 360, 2049-2065, 2005.

Bierhuizen, J. F.: The effect of temperature on plant growth, development, and yield, Proc. Uppsala Symp. Unesco 1970, 89-98, 1973.

Blum, A.: Improving wheat grain filling under stress by stem reserve mobilization, Euphytica, 100, 77-83, 1998.

Blum, A., Sinmena, B., and Ziv, O.: An evaluation of seed and seedling drought tolerance screening tests in wheat, Euphytica, 29, 727-736, 1980.

Bolinder, M. A., Angers, D. A., and Dubuc, J. P.: Estimating shoot to root ratios and and carbon inputs in soils for cereal crops, Agr. Ecosyst. Environ., 63, 61-67, 1997.

Bondeau, A., Smith, P. C., Zaehle, S., Schaphoff, S., Lucht, W., Cramer, W., Gerten, D., Lotze-Campen, H., Müller, C., Reichstein, M., and Smith, B.: Modelling the role of agriculture for the 20th century global terrestrial carbon balance, Glob. Change Biol., 13, 679-706, 2007.

Boote, K. J., Jones, J. W., and Hoogenboom, G.: Simulation of crop growth: CROPGRO model, in: Agricultural systems modeling and simulation, edited by: Peart, R. M. and Curry, R. B., Marcel Dekker Inc., New York, NY, 651-692, 1998.

Brooking, I. A.: Temperature response of vernalization in wheat: a developmental analysis, Ann. Bot. London, 78, 507-512, 1996. 
Brouquisse, R., Gaudillere, J., and Raymond, P.: Induction of a carbon-starvation-related proteolysis in whole maize plants submitted to light/dark cycles and to extended darkness, Plant Physiol., 117, 1281-1291, 1998.

Buchanan, M. and King, L. D.: Carbon and phosphorus losses from decomposing crop residues in no-till and conventional till agroecosystems, Agron. J., 85, 631-638, 1993.

Burgess, M. S., Mehuys, G. R., and Madramootoo, C. A.: Nitrogen dynamics of decomposing corn residue components under three tillage systems, Soil Sci. Soc. Am. J., 66, 1350-1358, 2002.

Buyanovsky, G. A. and Wagner, G. H.: Post-harvest residue input to cropland, Plant Soil, 93, 57-65, 1986.

Challinor, A. J., Wheeler, T. R., Craufurd, P. Q., Slingo, J. M., and Grimes, D. I. F.: Design and optimization of a large-area processbased model for annual crops, Agr. Forest Meteorol., 124, 99120, 2004.

Challinor, A. J., Wheeler, T. R., Slingo,, J. M., and Hemming, D.: Quantification of Physical and Biological Uncertainty in the Simulation of the Yield of a Tropical Crop Using Present-Day and Doubled $\mathrm{CO}_{2}$ Climates, Philos. T. R. Soc. B, 360, 2085-2094, 2005.

Clapp, R. B. and Hornberger, G. M.: Empirical equations for some soil hydraulic properties, Water Resour. Res., 14.4, 601-604, 1978.

Collar, C. and Askland, G.: Harvest stage effects on yield and quality of winter forage. Proceedings of the 31 st California alfalfa and forage symposium: 12-13 December, 2001, Modesto, CA, UC Cooperative Extension University of California, Davis, 2001.

Collatz, G. J., Ball, J. T., Griver, C., and Berry, J. A.: Physiological and environmental regulation of stomatal conductance, photosynthesis, and transpiration: A model that includes a laminar boundary layer, Agr. Forest Meteorol., 54, 107-136, 1991.

Collatz, G. J., Ribas-Carbo, M., and Berry, J. A.: Coupled photosynthesis stomatal conductance model for leaves of $\mathrm{C}_{4}$ plants, Aust. J. Plant Physiol., 19, 519-538, 1992.

Corbin, K. D., Denning, A. S., Lu, L., Wang, J. W., and Baker, I. T.: Possible representation errors in inversions of satellite CO2 retrievals. J. Geophys. Res.-Atmos., 113, D02301, doi:10.1029/2007JD008716, 2008.

Cornell University Cooperative Extension.: 2008 Cornell guide for integrated field crop management, Cornell University Cooperative extension, availale at: http://ipmguidelines.org/FieldCrops/ content/CH02/default.asp, 2008.

Dai, Y., Zeng, X., Dickinson, R. E., Baker, I., Bonan, G., Bosilovich, M., Denning, S., Dirmeyer, P., Houser, P., Niu, G., Oleson, K., Schlosser, A., and Yang, Z. L.: The common land model (CLM), B. Am. Meteorol. Soc., 84, 1013-1023, 2003.

Denning, A. S., Collatz, G. J., Zhang, C. G, Randall, D. A., Berry, J. A., Sellers, P. J., Colello, G. D., and Dazlich, D. A.: Simulations of terrestrial carbon metabolism and atmospheric $\mathrm{CO} 2$ in a general circulation model. Part 1: Surface carbon fluxes, Tellus B, 48, 521-542, 1996a.

Denning, A. S., Randall, D. A., Collatz, G. J., and Sellers, P. J.: Simulations of terrestrial carbon metabolism and atmospheric $\mathrm{CO}_{2}$ in a general circulation model. Part 2: Spatial and temporal variations of atmospheric $\mathrm{CO}_{2}$, Tellus, 48B, 543-567, $1996 \mathrm{~b}$.
Denning, A. S., Nicholls, M., Prihodko, L., et al.: Simulated variations in atmospheric $\mathrm{CO} 2$ over a Wisconsin forest using a coupled ecosystem-atmosphere model, Glob. Change Biol., 9(9), 1241-1250, 2003.

De Noblet-Ducoudré, N., Gervois, S., Ciais, P., Biovy, N., Brissson, N., Seguin, B., and Perrier, A.: Coupling the Soil-Vegetation Atmosphere Transfer Scheme ORCHIDEE to the agronomy model STICS to study the influence of croplands on the European carbon and water budgets, Agronomie, 24, 397-407, 2004.

Desjardins, R. L., Sivakumar, M.V.K,, and de Kimpe, C.: The contribution of agriculture to the state of climate: Workshop summary and recommendations. Agr. Forest Meteorol., 142(2-4), 314-324, 2007.

de Vries, P. F. W. T., Jansen, D. M., Ten Berge, H. F. M., and Bakema, A.: Simulation of ecophysiological processes of growth in several annual crops, Simulation Monographs, Wageningen (Netherlands): Pudoc., 271 pp., 1989.

Evans, L. S., Dimitriadis, L., and Hinkley, D. A.: Seed protein quantities of field-grown soybeans exposed to simulated acidic rain, New Phytol., 97, 71-76, 1984.

Farquhar, G. D., Caemmerer, S. V., and Berry, J. A.: A Biochemical-Model of Photosynthetic $\mathrm{CO}_{2}$ Assimilation in Leaves of C-3 Species, Planta, 149, 78-90, 1980.

Fehr, W. R., Caviness, C. E., Burmood, D. T., and Pennington, J. S.: Stage of development descriptions for soybeans, Glycine max (L.) Merrill, Crop Sci., 11, 929-931, 1971.

Fischer, M. L., Billesbach, D. P., Berry, J. A., Riley, W. J., and Torn, S.: Spatiotemporal variations in growing season exchanges of $\mathrm{CO}_{2}, \mathrm{H}_{2} \mathrm{O}$, and sensible heat in agricultural fields of the southern great plains, Earth Interactions, 11, E1231, doi: 10.1175/E1231.1, 2007.

Fowler, D. B.: Harvesting, Grain Drying and Storage, Winter wheat cereal production, available at: http://www.usask.ca/agriculture/ cropsci/winter_cereals/, 2002.

Gervois, S., de Noblet-Ducoudré, N., Viovy, N., and Ciais, P.: Including croplandsin a global biosphere model: methodology and evaluation of specific sites, Earth Interact., 8(16), 1-25, 2004.

Gent, M. P. N. and Kyomoto, R. K.: Assimilation and distribution of photosynthate in winter wheat cultivars differing in harvest index, Crop Sci., 29, 120-125, 1989.

Gomez-Macpherson, H., Richards, R. A., and Masle, J.: Growth of near-isogenic wheat lines differing in development- plants in a simulated canopy, Ann. Bot.-London, 82, 323-330, 1998.

Goudriaan, J. and Van Laar, H. H.: Modelling potential crop growth processes, Kluwer Academic Publishers, Boston, 1994.

Green, D. G. and Sudia, T. W.: Germination and seedling development of soybean in a carbon dioxide- deficient atmosphere, Am. J. Bot., 56(9), 1018-1022, 1969.

Gregory, P. J. and Atwell, B. J.: The fate of carbon in pulse-labelled crops of barley and wheat, Plant Soil, 136, 205-213, 1991.

Gregory, P. J., Palta, J. A., and Batts, G. R.: Root systems and root:mass ratio - carbon allocation under current and projected atmospheric conditions in arable crops, Plant Soil, 187, 221-228, 1997.

Hameed, A., Malik, S. A., Iqbal, N., Arshad, R., and Farooq, S.: Influence of hydrogen peroxide on initial leaf and coleoptiles growth in etiolated wheat (Triticum aestivum L.) seedlings, Asian Journal of Plant Sciences, 2(15-16), 1121-1125, 2003. 
Hanan, N. P., Berry, J. A., Verma, S. B., Walter-Shea, E. A., Suyker, A. E., Burba, G. G., and Denning, A. S.: Model analyses of biosphere-atmosphere exchanges of $\mathrm{CO}_{2}$, water and energy in Great Plains tallgrass prairie and wheat ecosystems, Agr. Forest Meteorol., 131, 162-179, 2004.

Hansen, J. W., Challinor, A., Ines, A. V. M., Wheeler, T., and Moron, V.: Translating climate forecasts into agricultural terms: advances and challenges, Clim. Res., 33, 27-41, 2006.

Hanway, J. J. and Weber, C. R.: Dry matter accumulation in eight soybean (Glycine max (L.) Merrill) varieties, Agron. J., 63, 227230, 1971a.

Hanway, J. J. and Weber, C. R.: Dry matter accumulation in soybean (Glycine max (L.) Merrill) plants as influenced by N, P, and K fertilization, Agron. J., 63, 263-266, 1971b.

Harley, P. C., Weber, J. A., and Gates, D. M.: Interactive effects of light, leaf temperatue, $\mathrm{CO}_{2}$ and $\mathrm{O}_{2}$ on photosynthesis in soybean, Planta, 165, 249-263, 1985.

Hay, R. K. M.: Harvest index: a review of its use in plant breeding and crop physiology, Ann. Appl. Biol., 126, 197-216, 1995.

Heard, J.: Nutrient accumulation and partitioning by grain corn in Manitoba, Proc. of 47th Annual Manitoba Society of Soil Science Meeting, available at: http://www.umanitoba.ca/afs/agronomists_conf/proceedings/ 2006/heard_nutrient_uptake_and\%20partitioning.pdf, 2004.

Hofstra, G. and Hesketh, J. D.: Effect of temperature on the gas exchange of leaves in the light and dark, Planta, 85, 228-237, 1969.

Hopkins, E. W., Peterson, W. H., and Fred, E. B.: The composition of the cells of certain bacteria with special reference to their carbon and their nitrogen content, J. Biol. Chem., 85(1), 21-27, 1929.

IPCC: Climate Change 2007: Synthesis Report, Cambridge University Press, Cambridge, 2007.

Jones, C. A. and Kiniry, J. R.: CERES-maize: A simulation model of maize growth and development, Texas A\&M Univ. Press, College Station, TX, 1986.

Kalnay, E., Kanamitsu, M., Kistler, R., Collins, W., Deaven, D., Gandin, L., Iredell, M., Saha, S., White, G., Woollen, J., Zhu, Y., Chelliah, M., Ebisuzaki, W., Higgins, W., Janowiak, J., Mo, K. C., Ropelewski, C., Wang, J., Leetmaa, A., Reynolds, R., Jenne, R., and Joseph, D.: The NCEP/NCAR 40-Year Reanalysis Project, B. Am. Meteorol. Soc., 77(3), 437-471, 1996.

Kiniry, J. R.: Maize phasic development, in: Modeling Plant Soil systems, edited by: Hanks, J. and Ritchie, J. T., Agronomy Monograph no. 31, ASA, CSSSA, SSSA, Madison, WI, 55-69, 1991.

Kiniriy, J. R.: Nonstructural carbohydrate utilization by wheat shaded during grain growth, Agron. J., 85, 844-849, 1993.

Kothavala, Z., Arain, M. A., Black, T. A., and Verseghy, D.: The simulation of energy, water vapor and carbon dioxide fluxes over common crops by the Canadian Land Surface Scheme (CLASS), Agr. Forest Meteorol., 133, 89-108, 2005.

Kucharik, C. J. and Byre, K. R.: IBIS yield and nitrate leaching predictions for Wisconsin maize agroecosystems receiving varied N-fertilizer, J. Environ. Qual., 32, 247-268, 2003.

Law, R. D. and Crafts-Brandner, S. J.: High temperature stress increases the expression of wheat leaf Ribulose-1,5-Bisphosphate Carboxylase/oxygenase Activase protein, Arch. Biochem. Biophys., 386, 261-267, 2001.
Lokupitiya, E., Breidt, F. J., Lokupitiya, R., Williams, S., and Paustian, K.: Deriving comprehensive county-level crop yield and area data for US cropland, Agron. J., 99(3), 673-681, 2007.

Los, S. O.: Estimation of the ratio of sensor degradation between NOAA AVHRR channels 1 and 2 from monthly NDVI composites, IEEE T. Geosci. Remote, 36(1), 206-213, 1998.

McMaster, G. S. and Wilhelm, W. W.: Is soil temperature better than air temperature for predicting winter wheat phenology?, Agron. J., 90(5), 602-607, 1998.

McWilliams, D. A., Berglund, D. R., and Endres, G. J.: Soybean growth and management quick guide. North Dakota State University Extension Service, available at: http://www.ag.ndsu.edu/ pubs/plantsci/rowcrops/a1174/a1174.pdf, 1999.

Meyers, T. P. and Hollinger, S. E.: An assessment of storage terms in the surface energy balance of maize and soybean, Agr. Forest Meteorol., 125(1-2), 105-115, 2004.

Morgan, P. B., Bernacchi, C. J., Ort, D. R., and Long, S. P.: An in vivo analysis of the effect of season-long open-air elevation of ozone to anticipated 2050 levels on photosynthesis in soybean, Plant Physiol., 135, 2348-2357, 2004.

Neild, R. E. and Newman, J. E.: Growing season characteristics and requirements in the corn Belt, National Corn Handbook NCH-40, Purdue University, West Lafeyette, IN, 1986.

Nicholls, M. E., Denning, A. S., Prihodko, L., Vidale, P. L., Davis, K., and Bakwin, P.: A multiple-scale simulation of variations in atmospheric carbon dioxide using a coupled biosphere-atmospheric model, J. Geophys. Res., 109, D18117, doi:10.1029/2003JD004482, 2004.

Nielsen, R.: Field Drydown of Mature Corn Grain. Corny News Network, Purdue Univ., available at: http://www.agry.purdue. edu/ext/corn/news/articles.05/GrainDrying-0815.html, 2005.

Nielsen, R. L.: Root Development in Young Corn. Corny News Network Articles. Agronomy Department, Purdue University, available at: http://www.agry.purdue.edu/ext/corn/news/ timeless/Roots.html, 2007.

Norman, J. M. and Arkebauer, T. J.: Predicting canopy light-use efficiency from leaf characteristics, in: Modeling Plant and Soil Systems, editedy by: Hanks, J. and Ritchie, J. T., Agronomy Monograph no. 31, ASA, CSSSA, SSSA, Madison, WI, 125143, 1991.

Oleson, K. W., Niu, G.-Y., Yang, Z.-L., Lawrence, D. M., Thornton, P. E., Lawrence, P. J., Stöckli, R., Dickinson, R. E., Bonan, G. B., Levis, S., Dai, A., and Qian, T.: Improvements to the Community Land Model and their impact on the hydrological cycle, J. Geophys. Res., 113, G01021, doi:10.1029/2007JG000563, 2008.

Osborne, T. M., Lawrence, D. M., Challinor, A. J., Slingo, J. M., and Wheeler, T. R.: Development and assessment of a coupled crop-climate model, Glob. Change Biol., 13, 169-183, 2007.

Pedersen, P.: How early can soybean be planted?, available at: http://www.ipm.iastate.edu/ipm/icm/2003/4-14-2003/ earlysoy.html, 2003.

Pedersen, P. and Lauer, J. G.: Soybean growth and development in various management systems and planting dates, Crop Sci., 44, 508-515, 2004.

Peterson, C. M., Klepper, B., and Rickman, R. W.: Seed reserves and seedling development in winter wheat, Agron. J., 81, 245251, 1989. 
Pielke, R. A., Cotton, W. R., Walko, R. L., et. al.: A comprehensive meteorological modeling system- RAMS, Meteorol. Atmos. Phys., 49(1-4), 69-91, 1992.

Pinhero, R. G. and Fletcher, R. A.: Paclobutrazol and ancymidol protect corn seedlings from high and low-temperature stresses, Plant Growth Regul., 15(1), 47-53, 1994.

Prince, S. D., Haskett, J., Steninger, M., Strand, H., and Wright, R.: Net primary production of US Midwest croplands from agricultural harvest yield data, Ecol. Appl., 11, 1194-1205, 2001.

Puckridge, D. W.: Photosynthesis of wheat under field conditions. The effect of solar elevation on the distribution of photosynthetic activity within the crop canopy, Aust. J. Agr. Res., 23, 397-404, 1972.

Randall, D. A., Sellers, P. J., Berry, J. A., Dazlich, D. A., Zhang, C., Collatz, C. J., Denning, A. S., Los, S. O., Field, C. B., Fung, I., Justice, C. O., and Tucker, C. J.: A revised land surface parameterization (SiB2) for atmospheric GCMs. Part 3: The greening of the CSU GCM, J. Climate, 9, 738-763, 1996.

Rao, M. S. S., Mullinix, B. G., Rangappa, M., Cebert, E., Bhagsari, A. S., Sapra, V. T., Joshy, J. M., and Dadson, R. B.: Soybean. Genotype $\mathrm{x}$ environment interactions and yield stability of foodgrad soybean genotypes, Agron. J., 94(1), 72-80, 2002.

Reekey, E. G. and Redmann, R. E.: Growth and maintenance respiration of perennial root systems in a dry grassland dominated by Agropyron dasystachyum (Hook.) Scribn, New Phytol., 105(4), 595-603, 1987.

Richardson, M. D. and Bacon, C. W.: Cyclic hydroxamic acid accumulation in corn seedlings exposed to reduced water potentials before, during and after germination, J. Chem. Ecol., 19(8), 1613-1624, 1993.

Ritchie, J. T.: Wheat phasic development, in: Modeling Plant Soil, systems. Agron. Monogr., edited by: Hanks, J. and Ritchie, J. T., 31, ASA, CSSSA, SSSA, Madison, WI, 31-54, 1991.

Ritchie, S. W., Hanway, J. J., and Benson, G. O.: How a corn plant develops. Special Report No 48, Iowa State University Science and Technology Cooperative Extension Service, Ames, IA, 1992.

Ritchie, S. W., Hanway, J. J., Thompson, H. E., and Benson, G. O.: How a soybean plant develops. Special Report No. 53, Iowa State University of Science and Technology Cooperative Extension Service, Ames, IA, 1996.

Schaefer, K., Denning, A. S., Suits, N., Kaduk, J., Baker, I., Los, S., and Prihodko, L.: Effect of climate on interannual variability of terrestrial CO2 fluxes, Global Biogeochem. Cy., 16(4), 1102, doi:10.1029/2002GB001928, 2002.

Schaefer, K., Denning, A. S., and Leonard, O.: The winter Arctic Oscillation, the timing of spring, and carbon fluxes in the northern hemisphere, Global Biogeochem. Cy., 19, GB3017, doi:10.1029/2004GB002336, 2005.

Schulze, R. E., Kiker, G. A., and Kunz, R. P.: Global climate change and gricultural productivity in southern Africa, Global Environ. Chang., 3(4), 330-349, 1993.

Sellers, P. J., Mintz, Y., Sud, Y. C., Dalcher, A.: A simple biosphere model $(\mathrm{SiB})$ for use within general circulation models, J. Atmos. Sci., 43, 505-531, 1986.
Sellers, P. J., Berry, J. A., Collatz, G. J., Field, C. B., and Hall, F. G.: Canopy reflectance, photosynthesis and transpiration. III. A reanalysis using improved leaf models and a new canopy integration scheme, Remote Sens. Environ., 42, 187-216, 1992.

Sellers P. J., Tucker C. J., Collatz, G. J., Los, S. O., Justice C. O, Dazlich D. A., and Randall, D. A.: A global 1-degrees-by-1degrees ndvi data set for climate studies .2. the generation of global fields of terrestrial biophysical parameters from the ndvi, Int. J. Remote Sens., 15(17), 3519-3545, 1994.

Sellers, P. J., Randall, D. A., Collatz, G. J., Berry, J. A., Field, C. B., Dazlich, D. A., Zhang, C., Collelo, G. D., and Bounoua, L.: A revised land surface parameterization (SiB2) for atmospheric GCMs. Part 1: Model formulation, J. Climate, 9, 676705, 1996a.

Sellers, P. J., Los, S. O., Tucker, C. J., Justice, C. O., Dazlich, D. A., Collatz, G. J., and Randall, D. A.: A revised land surface parameterization (SiB2) for atmospheric GCMs. Part II: The generation of global fields of terrestrial biophysical parameters from satellite data, J. Climate, 9, 706-737, 1996b.

Sharma, R. C., Smith, E. L., and McNew, R. W.: Stability of harvest index and grain yield in winter wheat, Crop Sci., 27, 104-108, 1987.

Smiciklas, K. D., Mullen, R. E., Carlson, R. E., and Knapp, A. D.: Soybean seed quality response to drought stress and pod position, Agron. J., 84, 166-170, 1992.

Silvius, J. E., Johnson, R. R., and Peters, D. B.: Effect of water stress on carbon assimilation and distribution in soybean plants at different stages of development, Crop Sci., 17(5), 713-716, 1977.

Spaeth, S. C., Randall, H. C., Sinclair, T.R., and Vendeland, J. S.: Stability of Soybean Harvest Index, Agron. J., 76, 482-486, 1984.

Suyker, A. E., Verma, S. B., Burba, G. G., Arkebauer, T. J., Walters, D. T., and Hubbard, K. G.: Growing season carbon dioxide exchange in irrigated and rainfed maize, Agr. Forest Meteorol., 124(1-2), 1-13, 2004.

Suits, N. S., Denning, A. S., Berry, J. A., Still, C. J., Kaduk, J., and Miller, J. B.: Simulation of carbon isotope discrimination of the terrestrial biosphere, Global Biogeochem. Cy., 19, GB1017, doi:10.1029/2003GB002141, 2005.

Takle, E. S., Pan, Z., Batchelor, W., and Chistensen, J. H.: Twoway coupling of crop-climate interactions in a regional climate model. 17TH Conference on Hydrology, AMS Meeting, Long Beach, CA, available at: http://ams.confex.com/ams/pdfpapers/ 56889.pdf, 2003.

Taylor, H. M., Mason, W. K., Bennie, A. T. P., and Howse, H. R.: Responses of soybeans to two spacings and two soil water levels. I. An analysis of biomass accumulation, canopy development, solar radiation interception and components of seed yield, Field Crop. Res., 5, 1-14, 1982.

Thornton, J. H., Goodrich, R. D., and Meiske, J. C.: Corn maturity. III. Composition, digestibility of nutrients and energy value of corn cobs and ear corn of four maturities, J. Anim. Sci., 29(6), 987-991, 1969.

Torbert, H. A., Prior, S. A., Rogers, H. H., and Runion, G. B.: Elevated atmospheric $\mathrm{CO}_{2}$ effects on $\mathrm{N}$ fertilization in grain sorghum and soybean, Field Crop. Res., 88, 57-67, 2004. 
Tucker, C. J., Pinzen, J. E., Brown, M. E., Slayback, D. A., Pak, E. E., Mahoney, R., Vermote, E. F., and El Saleous, N.: An extended AVHRR 8-km NDVI dataset compatible with MODIS and SPOT vegetation NDVI data, Int. J. Remote Sens., 26(20), 4485-4498, 2005.

USDA: Usual planting and harvesting dates for field crops, USDA, 1997.

Vanotti, M. B., Bundy, L. G., and Peterson, A. E.: Nitrogen fertilizer and legume-cereal rotation effects on soil production and organic matter dynamics in Wisconsin, in: Soil Organic Matter in Temperate Agroecosystems, edited by: Paul, E. A., Paustian, K., Elliott, E. T., and Cole, C. V., CRC Press, New York, 105-119, 1997.

Verma, S. B., Dobermann, A., Cassman, K. G., Walters, D. T., Knops, J. M., Arkebauer, T. J., Suyker, A. E., Burba, G. G., Amos, B., Yang, H., Ginting, D., Hubbard, K. G., Gitelson, A. A., and Walter-Shea, E. A.: Annual carbon dioxide exchange in irrigated and rainfed maize-based agroecosystems, Agr. Forest Meteorol., 131, 77-96, 2005.
Vidale, P. L. and Stockli, R.: Prognostic canopy air space solutions for land surface exchanges, Theor. Appl. Climatol., 80(24), 245-257, 2005.

Wang, J. W., Denning, A. S., Lu, L. X., Baker, I. T., Corbin, K. D., and Davis, K. J.: Observations and simulations of synoptic, regional, and local variations in atmospheric $\mathrm{CO}_{2}$, J. Geophys. Res., 112, D04108, doi:10.1029/2006JD007410, 2007.

Wells, R., Ashley, D. A., and Boerma, H. R.: Physiological comparisons of two soybean cultivars differing in canopy photosynthesis. I. Variation in vertical ${ }^{14} \mathrm{CO}_{2}$ labelling and dry weight partitioning, Photosynth. Res., 9, 285-294, 1986.

Wilhelm, W. W.: Dry-matter partitioning and leaf area of winter wheat grown in a long-term fallow tillage comparisons in the US Central Great Plains, Soil Till. Res., 49, 49-56, 1998.

Yamagata, M., Kouchi, H., and Yoneyama, T.: Partitioning and utilization of photosynthate produced at different growth stages after anthesis in soybean (Glycine max L. merr.): Analysis by longterm 13C labelling experiments, J. Exp. Bot., 38(193), 12471259, 1987. 